\title{
ESPAÑA Y LA CRISIS PORTUGUESA DE 1846
}

\author{
por \\ CRISTÓBal ROBLES JaÉN* \\ Universidad de Murcia
}

RESUMEN: Las relaciones bispano-portuguesas bay que entenderlas en el marco de la aproximación del régimen moderado español al conservador -cartistas, cabralistasportugués por sus afinidades y por motivos de seguridad interior. La estrecba colaboración entre ambos gobiernos cesa tras la caída de Costa Cabral y la formación del gabinete Palmela. La politica de reformas iniciadas por el gobierno portugués y su negativa a contar con la anuencia del embajador español en Lisboa para que los emigrados politicos españoles fijasen su residencia, fueron duramente criticadas en España por los sectores más conservadores. España no toleraria que Portugal se convirtiera en su base de operacioner. Istúriz ordenó la aproximación de tropar a la frontera y se negó a ejercer el control deseado por las autoridades portuguesas sobre Costa Cabral en su exilio madrileño.

Palabras clave: Costa Cabral. Cabralista. Cartista. España. González Bravo. Istúriz. María da Fonte. María II. Palmela. Portugal. Progresista. Septembrista.

- Al autor del presente trabajo le fue concedida por el Ministerio de Educación y Cultura una licencia por estudios durante el curso académico 1997-1998 para la realización de la tesis doctoral España y la Guerra Civil en Portugal (1846-1847), dirigida por el Dr. Juan Bta. Vilar, de la que forma parte este artículo.

SIGLAS:

AAE CP: Archive duMinistère des Affaires Étrangères, Correspondence Politique, volume, Paris.

AAE MD: Archive du Ministère des Affaires Étrangères, Mérnoires et Documents, volume, Paris.

AHN: Archivo Histórico Nacional, sección, legajo y expediente, Madrid.

AMAE H: Archivo del Ministerio de Asuntos Exteriores, sección histórica, Madrid.

ANTT MNE: Archivos Nacionais Torre do Tombo, Miniscério dos Negocios Estrangeiros, caixa, Lisboa.

ASV SS: Archivio Segreto Vaticano, Segretaria di Stato, rubrica, fascicolo, foglio.

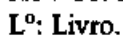

OLA: O Livro Azul ou Correspondencia relativa aos Negocios de Portugal, Lisboa, 1847.

R: reservado. 
ABSTRACT: Spanish-Portuguese relations in 1846 must be understood againat the backdrop of the proximity between the moderate Spanish regime to the conservative Portuguese chartists and supporters of Costa Cabral, arising from their affinity and from reasons of internal security. The close collaboration between the two governments ended after the fall of Costa Cabral and the formation of the liberal Palmela cabinet. The reformist policy initiated by the Portuguese government and its refusal to collaborate with the Spanish ambassador in Lisbon in fixing the residence of Spanish political exiles were strongly criticized in more conservative quarters in Spain. Isturiz ordered troops sent to the frontier and refused to exercise the control desired by the Portuguese autborities over Costa Cabral in bis exile in Madrid.

KEY wORDs: Costa Cabral. Cartistas. Istúriz. González Bravo. María da Fonte. María II. Portugal. Progresistas. Cabralistas. Septembristas.

Hubo un movimiento popular contra el gobierno de Lisboa provocado por unas medidas que modificaban hábitos seculares. La reacción afectó a la política interna de Portugal, a sus relaciones con España y al equilibrio de influencias conseguido entre Francia y el Reino Unido en Lisboa y Madrid.

En el fondo, las resistencias al proyecto de modernización del liberalismo doctrinario. La escisión de los liberales hasta formar fracciones irreconciliables, la ambigua posición constitucional de la Corona, la exigua representación de la sociedad en la opinión, en las Cámaras y el gobierno, la existencia de una fuerza política que convierte su disidencia en insurrección, el desajuste entre una gran masa de la población rural y preindustrial y la minoría, urbana e ilustrada, la contradicción entre los intereses de los distintos sectores de ésta, el papel decisivo de un ejército que, en este primer momento del liberalismo, es un agente vertebrador de la identidad nacional... son éstos algunos de los elementos que aparecen en esta crisis. La inestabilidad de las instituciones liberales explica que, ya en esta segunda parte de la primera mitad del XIX, éstas se hallen vinculadas a la "situación occidental» de España y Portugal. Su expresión fue entonces la Cuádruple Alianza. La solidaridad de Francia y del Reino Unido frente a la agresión de carlistas y miguelistas sobrepasaba la defensa dinástica de Isabel II y de María II. Tenía un horizonte político, cuya dimensión europea era innegable: un bloque liberal frente a la alianza de las potencias que combatían la monarquía constitucional.

Hasta 1834 absolutistas y liberales vivieron en Portugal en conflicto. La Convención de Évora-Monte y los artículos adicionales al Tratado de la Cuádruple Alianza, firmados ese mismo año, desalojaban a los primeros definitivamente del poder. Vinieron luego las discrepancias. Los liberales se dividieron en cartistas y septembristas. Los primeros, moderados y conservadores. Representaban esa posición doctrinaria que buscaba el encuentro de los vencidos con las nuevas instituciones políticas'. Los otros creían que nada había cambiado

1 Carlos Seco ha puesto de relieve ese aspecto de la personalidad y de la obra de Narváez en su introducción a Jesús PABÓN, Narváez y su época, Madrid 1983. 
desde su derrota. Nada habrían aprendido de ella ni en su exilioº ${ }^{2}$ Ambos defendían modelos constitucionales diferentes. Para los septembristas, la nación estaba por encima del Rey. Para los cartistas, el Rey tenía un poder propio, legitimado por su función moderadora y que tenía su expresión en su facultad para "otorgar» la constitución. Esta diseñaba un legislativo bicameral que unía representación y herencia ${ }^{3}$. La doctrina política del cartismo pretendía conciliar el poder real y la soberanía de la nación, salvando en lo posible las prerrogativas tegias ${ }^{4}$. Era la versión portuguesa del moderantismo ${ }^{5}$. El cartismo era, fundamentalmente, una forma de entender la vida política ${ }^{6}$ Un ejercicio del liberalismo en el ámbito político?

Estos años, en Oporto, los comerciantes más importantes, tanto portugueses como extranjeros, estaban al lado de los cartistas. Las clases ligadas a la industria -fabricantes, artesanos y obreros-- y la pequeña burguesía comercial se identificaban con el ideario septembrista ${ }^{8}$.

2 «Desde a primeira hora da consolidaçāo do regime liberal, desentharam-se com vigôr duas correntes políticas bens diferentes: a dos cartistas, liberais moderados, conservadores, que queriam a Carta Constitucional como un acto de coerência e de moral políticas, pois en nome dela se fizera tôda a campanha de 1826 a Evora Monte; a dos que pretendiam reatar as tradiçōes vintistas, alimentados pelos que nada tinham aprendido no exílio. A história da nossa vida política dêste período de 34 até à Regeneração, é a de embates, ora por baixo ora por cima, dessas duas funçōes irreductíveis". Marques Guedes, A.: A alianģa inglêsa, Lisboa 1938, 307. Marques Gomes, J. A.: Luttas caseiras. Portugal de 1834 a 1851 , Lisboa 1894.

${ }^{3}$ FerReIRA BoRges, J.: Exame critico do valor politico das expressoes soberania do povo e soberania das cortes $e$ outro sim das bases da organizaçäo do pader legislativo no sistema representativo $\varepsilon$ da sançä́o do rei, Lisboa 1837.

4 En ella, «... os poderes do Estado passaram a ser quatro, em vez de três, o legislativo, o moderador, o executivo e o judicial". PRAÇA, L.: Estudos sobre a Carta Constitucional de 1826 e Acto Adicional de 1852, Coimbra 1880. SARAIVA, A. J.: Herculano e o liberalismo em Portugal, Lisboa 1949. CAETANo, M.: Ciência política e direito constitucional, Coimbra 1955, y Constituif̧ôes portuguesas, Lisboa 1978. MarTins, R: A Carta Constitucional, lisboa s. d.

5 «Otden público, autoridad, centralismo, mantenimiento de los supuestos sociales y resistencia a toda nueva subversión: tal era el desiderátum de los moderados, en el que éstos cifraban el bien y la felicidad». J. L. Comellas, Los maderados en el poder, 1844-1854, Madrid 1970, 149. Dínz DeL CORRaL, L.: El liberalismo doctrinario, Madrid 1945.

6 «O cartismo é, sobretudo, un modo específico de encarar a administraçāo pública, é o respeito pelos compromisos políticos assumidos e pela lealdade jurada, é, também, um conceito muito concreto de paz civil, de actividade económica, de cultura, de municipalismo e de realeza; em suma, é um código de conduta política que o cidadāo carrista deve assumir conscientemente e promover, na prática, através das suas actividades cívicas». CRuz CANAVEIRA, M. F.: Liberais maderados e Constitucionalismo maderado (1814-1852), Lisboa 1988, 110.

7De ello habló Gregotio Marañón en su Ensayos Liberales, Madrid 1979. Insiste también en el liberalismo como un sistema de creencias que incluye la colerancia, HAYEK, F. A.: Los fundamentos de la libertad, Madrid 1975.

8 SuberT, A.: Cbartisme et septembrisme. La vie politique à Porto de 1836 à 1839 daprès les consuls frangais: Bulletin des Érudes Portugaises, (1953), 1-28. TeNGarRINHA, J.: O liberalismo português no século XIX, Lisboa 1981. Moral RUIZ, J. del: La penetración del liberalismo en Portugal, 1814-1834:

Hispania, LX/3, núm. 206 (2000) 1001-1046 
Muerto Pedro IV, que ejercía como regente, se decretó en septiembre de 1834 la mayoría de edad de su hija María II ${ }^{9}$. Hubo hasta 1836 ministerios moderados, casi todos ellos presididos por el duque de Palmela ${ }^{10}$, el marqués de Saldanha ${ }^{11}$ y el duque de Terceira ${ }^{12}$. Gobernaron con la Carta Constitucional otorgada por Pedro IV el 29 de abril de 1826. Fue tan decisiva en su promulgación la intervención británica que, hasta 1847 , miguelistas y septembristas la tacharon de extraña a la nación.

En la oposición a estos gobiernos moderados se encontraban los liberales radicales y los absolutistas o miguelistas puros ${ }^{13}$. Hubo entre ellos un entendi-

Notas sobre la utilización de fuenter documentales no comencionales para el analisis de las confrontaciones ideologicar: Actas del Coloquio Internacional: La prensa en la revolución liberal: España, Portugal y América Latina, Alberto Gil Novales (coord.), Madrid 1983, 32.

9 Duarte de Almeida e Araujo, F.: Crónica da ratinha a senhora $D^{a}$ Maria $I$, 3 v. Lisboa 1857-1861. FonseCA, F. da: Rainhas de Portugal, Lisboa 1879. TeIXeIra De VASCONCELOS, A. A.: Les contemporains portugais, espagnols et brésiliens. Le Portugal et la Maison de Bragance, París 1859 . MOUZINHO DE ALBUQUERQUE, J.: Juizo crítico sobre os actos de Administraşäo finda com a morte de sua magestade a senhora $D^{a}$ Maria $I I$, que Deus baja, Lisboa 1854. Lemos, E. de: $D^{a}$ Maria II (A rainba e a mulher), Lisboa 1954. DA SILveira, M.: Memória aceria do restabelecimento da Carta Constitucional e do trono de D. Maria II, Lisboa 1983.

10 LOPES DE MENDOCA, A. P. Noticia bistórica de duque de Palmela, Lisboa 1859 y Despachos e correspondência do Duque de Palmela 4 vs., J. J. dos Reis e Vasconcelos (ed.), Lisboa 1851-1869. Rebelo DA SIlvA, L. A.: Varôes ilustres das três epocas constitucionais, Lisboa 1870 . VAZ DE CARVALHO, Ma A.: $A$ vida do duque de Palmela D. Pedro de Sousa e Holstein, 2 vs., Lisboa 1898-99. J. CARlos FeIo CARDOSO E VISCONDE DE SANCHES DE BAENA, Memórias bistóricas genealogicas dos duques portugueses do século XIX, Lisboa 1883. Campos, C. de: $A$ Baronesa de Stael e o Duque de Palmela. Lisboa 1901. MARTINS, R: Palmela na emigraşäo: estudo sobre cartas inéditas. Lisboa 1915. Un retrato psicológico del duque, OLIVEIRA MarTins, Portugal contemporaneo, I, Mira-Sintra 1996, 154-157.

11 Los escritos de Saldanha y las polémicas que suscitaton pueden verse en Francisco Da SILVA, I.: Diccionário bibliográfico portuguê̂, vs. III y X. Lisboa 1859 y 1883. D. ANTONIO DA COSTA, Historia do manechal Saldanba, Lisboa 1879. G. J. C. HenRIQUes (da CARNOTA), Correspondencia do Marechal Duque de Saldanba. 2 vs. Lisboa 1904-1905. CosTA LOBO, F. M.: O Marechal Duque de Saldanha, Lisboa s. d. Cesar DA Suva, O marechal Saldanha, Lisboa s. d. Ouveira Martins, Perfi, Lisboa 1930, y Portugal ..., o. c. I, 294-300. PIMENTA, B.: O marechal Saldanha, stua vida militar, stuas ideias e métados, 3 vs., Coimbra 1957. ZuQuete, A. M.: Nabreza de Portugal, vol. Lli, Lisboa 1961.

${ }_{12}^{2}$ ZUQuete, A. M.: Nobreza .... o. c. NoronHA, E. de: Os marechais de Da Maria II, Lisboa s. d. MARTINS, R.: $O$ duque de Terceira, Lisboa s. d.

13 Para este período los trabajos de Moral Ruz, J. del: España y Portugal, 1823-1834. Los inicios de los movimientos absolutistas. Memoria de licenciatura, Universidad Complutense 1971, y Portugal, 1820-1834. Contribución al estudio de las bases económicas, sociales y politicas del miguelismo, tesis doctoral, Universidad Complutense, Madrid 1976; Realistas, miguelistas y liberales. Contribución al estudio de la intervención española en Portugal (1826-1828): EI siglo XIX en España: doce estudios, J. M. Jover (ed.), Barcelona 1974, 239-252; Las sociedades secretas ultratrealistas de España y Portugal (1821-1832): Sistema 8 (1975) 31-56; La Hacienda portuguesa en la crisis final del Antiguo Régimen (1798-1833): O liberalismo na Península Ibérica na primera metade do século XIX, II, Lisboa 1982, 175-197; La penetración del liberalismo en Portugal ..., o. c., 31-36; Portugal y España, 1820 . 1930. Perspectiva contemporánea: Actas dos Primeiros Cursos Internacionais de Verao de Cascais, Cascais 1995, 415-426 y BuLLón DE MENDozA, A.: Carlismo y miguelismo: Portugal e o mundo - do 
miento implícito, que en ocasiones llegaría a considerar a la Reina como enemiga común ${ }^{14}$. Entre los más radicales, los hermanos José y Manuel da Silva Passos, este último más conocido como Passos Manuel ${ }^{15}$. Acogían favorablemente sus discursos ciertos círculos de Lisboa y Oporto, influidos por la prensa y algún club, como la Sociedad Patriótica Lisbonense, donde Soares Caldeira, Leonel Tavares o Costa Cabral defendían el liberalismo democrático.

\section{LAS CONSTITUXENTES DE 1837}

Disuelto el Parlamento en junio de 1836, se convocó nuevas elecciones. La oposición, que había triunfado en ambas Beiras, Algarve y, sobre todo, en el Duero ${ }^{16}$, planeó un golpe de Estado revolucionario, que se inició el 9 de septiembre ${ }^{17}$. Los radicales pretendían acabar con la corrupción instalada en las instituciones políticas. Querían evitar el descrédito del liberalismo. Passos Manuel ocupó el poder. Abolió la Carta y puso en vigor la Constitución de 1822, primer texto constitucional portugués. Basada en la de Cádiz, enumeraba los derechos y deberes individuales. Afirmaba la soberanía de la nación y aceptaba la división e independencia de los tres poderes. Entre sus límites jurídicos y políticos, el rechazo al sufragio universal masculino, pues «a concessão do direito de voto a todos os varōes que soubessem ler e escrever punha em perigo os interesses dos propietários e dos homens de negócios». Sus adversarios vieron disminuir su hegemonía ${ }^{18}$.

pasado ao presence, Cascais 1995, 179-207. TORRE GOMEZ, H. de la: Historiografia española del Portugal contemporáneo: La Historia en el 96, Celso Almuiña (ed.), Madrid 1997, 65-80.

14 La coincidencia de intereses políticos entre radicales y miguelistas, frente a moderados y María II, que se repetiría en el campo de batalla durante la Patuleia, M. F. Cruz Canaveira, Liberais moderados..., o.c., 76-79.

is Manso Preto, J.: Manuel da Silva Passos. Noticia biographica: ao partido liberal, Lisboa 1874.

${ }^{16}$ de MIRANDA, S. A Revolugāo de Setembro de 1836. Geografia Eleitoral, Lisboa 1982. BONIFAcıo, $\mathbf{M}^{\mathrm{a}} \mathrm{F}^{\mathrm{a}}$ : A Revoluçäo de 9 de Setembro de 1836: a lógica dos acontecimentos: Análise Social 18 (1982), 331-370.

17 DUQUE VIEIRA, B. $\mathbf{M}^{2}: A$ revoluşāo de setembro e a discussāono constitucional de 1837, Lisboa 1987. De ARRIAGA, J.: História da revoluģäa de setembro, Lisboa s. d. y V. de SÁ, A revoluçäa de setembro de 1836, Lisboa s. d. Sobre la tevolución de septiembre vid. bibliografía en TENGARRINHA, J.: La bistoriografía portuguesa en los áltimos veinte años: La historia en el 96. Celso Almuiña (ed.), Madrid 1997, 19-63.

18 \&Nâo satisfazia a nobreza, nem a clero (nenhum dos quais recebia quaisquer prerrogativas), nem o rei, cujos poderes ficavam praticamente reducidos a nada». OLIVEIRA MARQUES, A. H. de: Historia de Portugal III (2), Lisboa 1981, 54-55. ARRIAGA, J. de: História da revolugfäo portuguesa de 1820, 4 vs. Oporto 1887. FONTES, A.: A revolução de 1820 e a constituiçāo de 1822, Lisboa 1932. Sobre la influencia de las constituciones revolucionarias francesas en la portuguesa de 1822, SlLBERT, A.: Révolution frangaise et tradition nationale: le cas portugats: Revista Porruguesa de História XXIII (1987) 31-52. RODRIGUES DA SiLVA, J.: O constitucionalismo setembrista e a revoluģäo francesa: 
Pasados dos meses, María II y su corte, logrado un acuerdo con el partido cartista y teniendo el consentimiento del embajador británico en Lisboa, Howard de Walden, intentaron del 2 al 4 de noviembre un golpe contrarrevolucionario, la «Belenzada». Decidió entonces el gobierno convocar elecciones a Cortes constituyentes. Se pactaría un texto con elementos de la Constitución de 1822 y de la Carta de 1826.

Iniciados los trabajos en enero de 1837 , cesaron los poderes dictatoriales del gobierno. Passos Manuel dimitió en mayo del mismo año. Le sucedió Sá da Bandeira, un liberal ordeiro ${ }^{19}$, es decir, un septembrista moderado, más próximo política, social, económica y culturalmente a los cartistas que a los radicales ${ }^{20}$.

Intentaton los cartistas recuperar el poder por la fuerza entre julio y septiembre de 1837 en Chao da Feira, y en Ruivaes, en septiembre del mismo año. Acudieron a los mariscales Saldanha y Terceira ${ }^{21}$. Éstos, para dar al proyecto un sentido más amplio, llamaron a Mouzinho de Albuquerque. Querían una regencia que asumiese el gobierno mientras durase lo que denominaron «la coacción de Su Majestad». El primer acto de este triunvirato fue publicar un manifiesto. Reconocían la Carta como única ley fundamental de la monarquía y anulaban todos los actos políticos de los gobiernos posteriores al 9 de septiembre de 1836. Los septembristas criticaron el apoyo británico a la revuelta acusándolos de actuar por razones económicas ${ }^{22}$.

Como sucedió en la "Belenzada», el pueblo de Lisboa defendió los logros revolucionarios, entre ellos, las milicias populares de la Guardia Nacional. A su lado, un sector septembrista del ejército, encabezado por el marqués de Sá da Bandeira y el vizconde das Antas. Juntos impidieron que la Reina hiciese dimitir a Sá da Bandeira. La Convención de Chaves incluyó en sus acuerdos que los dos mariscales cartistas salieran del país.

Revista de História das Ideias 10 (1988), $475-483$ y As cortes constituientes de 1837-1838: liberait em confronto, Lisboa 1992.

19 Sobre los «ordeiros», Oliveira Martins, Portugal ... , o. c., II, 115-122 y M. F. Cruz Canaveira, Liberais moderados ..., o. c., 81-82.

${ }^{20}$ Melreles, A.: O marquês da Sá da Bandeira, Lisboa 1876. Luz SoruANo, S. J. da: Vida do marquês da Sá da Bandeira, 2 vs. Lisboa 1887-1888. CAMPos, H. de: Garret e Sá da Bandeira, Lisboa 1938.

21 ANÓNIMO, Breve exposição do esforço tentado em fawor da Carta Constitucional em Portugal nos meses de julbo a outubro de 1837, s. 1. 1837. GOBLET D'AlviELlA, L'etablissment des Cobourg en Portugal, París 1869. de SÁ DA BANDEIRA, M.: Lettre adressée an comte Goblet d'Alviella, Lisboa 1870.

22 «C'était ... plutôt la lutte du commerce extérieur contre l'industrie nationale que celle des principes politiques que remuait les esprits à Porto... Pendant la révolte des maréchaux la responsabilité des Anglais fur sans cesse dénoncée du côté septembriste. Au début d'août la 'Vedeta' les accuse de soudoyer les insurgés par rancune contre le nouveau tarif ... Mais rien n'illustre mieux l'utilisation de ce sentiment, général sans doute mais par la force des choses beaucoup plus violent chez les industriels, que la proclamation du Vicomre de Antas dans laquelle il annonce la victoire sur les insurgés, le 18 septembre 1837 ». A. Silbert, Chartisme ..., o. c. , 16 y 21.

Hispania, LX/3, núm. 206 (2000) 1001-1046 
Las Cortes constituyentes culminaron sus trabajos en marzo de 1838. Pronto hubo algunos que estimaban traicionados los principios de la revolución. Ese mismo mes, los radicales se rebelaron contra el gobierno de Sá da Bandeira. Para ellos el texto constitucional elaborado tenía todos los inconvenientes de las Cartas otorgadas y ninguna de las ventajas de las constituciones liberales y democráticas ${ }^{23}$.

El 4 de abril, María II juró la Constitución. Similar a la belga de 1831 y a la española de 1837, contemplaba la sustitución de la Cámara de Pares hereditaria por un Senado electivo. La Cámara de Diputados se formaba mediante elecciones directas. Desaparecía el poder moderador otorgado en la Carta al rey, a quien se reconocía, sin embargo, la facultad de disolver las Cámaras y vetar leyes. Fruto de un compromiso entre cartismo y septembrismo, «a constituição de 1838 tinha sido acceita e jurada por todos os partidos - todos se tinham reunido em volta della, como campo neutro de discussão, como principio commum de conclusão' ${ }^{24}$. Fue acatada por los cartistas y permitió el regreso de los mariscales Saldanha y Terceira que se hallaban exilados.

Los radicales promovieron en julio tumultos populares en Lisboa. Los desórdenes endurecieron al gobierno, que adoptó actitudes cada vez más autoritarias. Si los septembristas defendían el principio de igualdad, los cartistas abogaban por el de libertad en orden.

La estrategia de desarrollo económico de los septembristas difícilmente podría tener éxito sin estabilidad política. Los moderados no tocaron la estructura económica tradicional del país. Las reformas que efectuaron en él fueron insignificantes.

\section{RIQUEZA, EJÉRCITO Y BUROCRACIA: EL CABRALISMO}

La vigencia de la Constitución de 1838 fue breve. Durante los varios gabinetes de Pinto Pizarro, el conde de Bonfim y Joaquim António de Aguiar, los cartistas fueron a más. A finales de 1841, con mayoría en el legislativo, tenían una gran influencia en los miembros del gobierno. Uno de éstos, Costa Cabral, era ministro de Justicia desde $1839^{25}$. Gran maestre de la masonería portugue-

${ }^{23}$ ARringa, J. de: História ..., o. c., III, I60-161, citado por M. F. Cruz Canaveira, Liberais moderados ..., o. c., 82.

24 Prólogo de Intervençäa estrangeira ox dosumentas bistoricos sobre a intervenção armada de Franga, Hespanba e Inglaterra nos negocios internos de Portkgal no anno de 1847. Oporto 1848. Recopilación de documentos mandados imprimir por Das Antas.

25 ANónimo, A. B. da Costa Cabral. Apontamentos bistóricos, Lisbaa 1844. Costa Cabral em relevo (2), Lisboa 1844. SERRĀO, J.: Relance sobre a vida quotidiana de Lisboa no tempo dos Cabrais: Temas Oitocentistas, I, Lisboa 1959.

Hispania, L.X/3, núm. 206 (2000) 1001-1046 
sa desde $1841^{26}$, encabezó en Oporto la oposición más conservadora. Proclamó la Carta el 27 de enero de $1842^{27}$ pues la Constitución de 1838 «no respetaba las prerrogativas políticas del trono". El manifiesto convertía la Carta en una imposición revolucionaria. Por esa razón, los moderados históricos rechazaron el procedimiento utilizado.

La reina nombró el 7 de febrero un gobierno presidido por Palmela. Costa Cabral decidió marchar sobre Lisboa. En Coimbra forzó la adhesión del nuevo presidente a la asonada con la promesa, incumplida, de revisar la Carta. El 9 de febrero María II designaba nuevo ministerio bajo la presidencia del duque de Terceira. Costa Cabral aparecía como ministro del Reino.

Base de este movimiento político fue un cambio social, que afectaba sobre todo a Oporto. El carácter industrial del septembrismo explicaba su caída. Meses antes de la «Revuelta de los Mariscales», los comerciantes de la ciudad variaron su opinión política. El motivo, la implantación de la tarifa que gravaba las importaciones y un decreto que equiparaba los derechos de entrada de los vinos de Villanueva de Gaya con los de Oporto. Perjudicados por el proteccionismo de los gobiernos septembristas, se pasaton a los cartistas y secundaron a Costa Cabral. Era una alianza anormal entre quienes vivían del comercio exterior y los que deseaban tarifas altas para los productos de importación. A pesar de que no podían abastecerlo, se reservaban en exclusiva el mercado.

Costa Cabral había girado desde el septembrismo al cartismo. Para entender sus motivos, hay que recordar el intento de estabilidad institucional del liberalismo en Portugal llevado a cabo por Passos Manuel en 1836 y 1837 basándose en la Constitución de 1822. Su experiencia le enseñó cómo debía gobernar: «năo só com uma ideia, uma doutrina, um objectivo, um apoio político interessado, uma função social, mas também com 'ordem' e meios práticos, imediatos e efectivos, com as suas finalidades bem à vista. Considerava-se que a riqueza do país existia, só precisava de estímulo e condições de desenvolvimen-

\footnotetext{
26 «... Costa Cabral, que se encontraba a la cabeza del gobierno, conspiraba con el ejército desde tan alto puesto contra su propio partido. Formóse bajo su dirección una sociedad militar, dividida en logias, perteneciendo a cada una los oficiales de los cuerpos. Para que la disciplina no padecieta, el jefe del cuerpo era el jefe de la logia y cada dos cuerpos formaban un mando superior militar. con un Consejo de cinco a siete hombres políticos de importancia. Los clubs de esta Sociedad eran los propios gobiernos de provincia. Como no podía menos de suceder con semejantes procedimientos, dióse pronto en Oporto el grito favorable a la Carta, reuniéndose seis regimientos de infantería, dos de caballería y algunos cañones. El mismo Costa Cabral, que había acudido a ponerse a la cabeza de estas fuerzas, marchó con ellas sobre la capital». FERNÁNDEz dE CÓRDOBA, F.: Mis memorias intimas, III, Madrid 1966, 82. CASTROGA, F.: A magonaria e a restauraf̧äo da Carta Constitucional em 1842. 0 golpe de Estado de Costa Cabral: Revista de História das Ideias 7 (1985) 155-181

$27 \mathrm{~A}$. Silbert ha destacado la indiferencia con la que se reaccionó ance el golpe de Costa Cabral. «Porto, le rempart des frères Passos, le foyer de la démocratie jacobine,ainsi changé! Acclamant la reine! Sans un vivat pour la nouvelle Constitution", Chartisme ..., o. c., 11. Pata la posición de Inglaterra, BONIFACIO, $\mathrm{M}^{\mathrm{a}}$. $\mathrm{F}^{\mathbf{a}}$.: 1834-1842: a Inglaterra perante a evoluģäo politica portkgkesa (bipbteses para a revișäo de verrôes correnter): Análise Social XX (1984), 467-488.
} 
to. O estímulo eram os transportes; as condiçōes, a ordem e a estabilidade governativan.

La carencia de medios económicos aumentaba las dificultades para lograr esa meta. Era esencial reorganizar el Estado como máquina administrativa. Se necesitaba reforzar la autoridad del poder central. De ahí su decidido apoyo al restablecimiento de la Carta en enero de 1842. Se iniciaba así el cabralismo o cartismo ortodoxo, radicalmente conservador, abanderado del orden y el desarrollo económico.

La política a seguir por Costa Cabral estaba bien definida: «centralização, reforma judiciária, fiscal e administrativa, construçäo de estradas, defesa da produção vinícola, alargamento da instrução, aumento de outras produçōes agrícolas, fomento e procura de mercados externos e internos. Costa Cabral e os seus partidários, nas Câmaras e nos jornais declaravam que o difícil nessa política estava em realizá-la, no estado em que se encontrava o país, con 'fraqueza de direção'. A firmeza do Estado era assi, o mais importante: sem ordem todas as tentativas de reforma seriam vãs» ${ }^{28}$.

A su lado, la aristocracia liberal terrateniente, comercial y financiera, que prosperó a partir de la compra de los bienes nacionales procedentes de la extinción de las órdenes religiosas en 1834. Junto a éstos, los funcionarios y gran parte del ejército. Riqueza, ejército y burocracia eran su base social. Su doctrina, centralización. Su forma de gobierno, oligarquía.

Tras los sucesos del 27 de enero de 1842 en Oporto y la instalación en el poder de los cabralistas, el 18 de marzo de ese mismo año se aprobó el nuevo Código Administrativo. Inspirado en el liberalismo autoritario, consagraba la hegemonía del Estado, que podía obligar a las poblaciones a obedecer las nuevas leyes, pagar impuestos, y aceptar las exigencias de un poder centralista.

Entre los años 1842 y 1846 , el gobierno cabralista impulsó la especulación financiera, pero posibilitó el desarrollo material. EI objetivo económico, estimular y establecer las condiciones necesarias para fomentar la riqueza del país. El restablecimiento de la Carta lo haría posible. Era un modelo parecido al que estaba funcionando en España. Por eso "Costa Cabral fue también de todos los cartistas portugueses el hombre preferido por los moderados de Madrid, cuya política de desarrollo capitalista, organización administrativa y dictadura civil era en todo comparable a la programada por el régimen español».

Las principales reformas desarrolladas por la acción de gobierno de Costa Cabral fueron el nuevo Código Administrativo, la reorganización de la Guardia Nacional, la reforma de las Cámaras Municipales, la reforma de la enseñanza secundaria, la normalización de las relaciones con la Santa Sede y las obras pú-

${ }^{28}$ Tras la victoria definitiva del liberalismo, era necesario a... que se organizasse uma forma efectiva e regular do governo, tanto central como regional e que restabelecesse a segurança publica». MACEDO, J. de: $O$ aparecimento em Partegal do programa político: Revista Portuguesa de História XIII (1971), 382-384 y 400-401. 
blicas y de fomento. Había pues una comunidad de intereses entre cartistas y moderados, sociológica y económica ${ }^{29}$.

Cuando comenzó a sentir que el gobierno entraba en aspectos primordiales de su existencia diaria, el pueblo reaccionó. Hubo representaciones sobre los nuevos impuestos y sobre las «Misericórdias» y obras pías en Braga, Aveiro, Villa de Feria, Guarda y Chaves. También lo hicieron entidades, como la Associação Mercantil Lisbonense.

Además de esta repuesta pacífica hubo algunos motines. Destacan los enfrentamientos con algunas municipalidades. Las de Évora, Villa Franca y Faro habían pedido la dimisión del ministerio, al que negaban su confianza. La respuesta fue contundente: cese de todos sus componentes ${ }^{30}$. Pocos meses después, el 4 de febrero de 1844 se produjo un pronunciamiento militar septembrista en Torres Novas. Lo dirigían el coronel A. César de Vasconcellos y José Estêvao, oficial de artillería. Pudo haber injerencias ${ }^{31}$ y conmitancias con algunos incidentes en España $a^{32}$. Costa Cabral dispuso de poderes extraordinarios y discrecionales en todo el teino. Los sublevados fueron derrotados en Almeida ${ }^{33}$.

Pero el levantamiento popular más importante se localizó en la región del Minho durante la primavera de 1846. Lo aptovecharon los enemigos de Costa Cabral para desplazarlo del poder.

Sus modales rudos en las tareas de gobierno sin poner límites en su violencia contra la oposición política y diversos escándalos políticos y financieros ${ }^{34}$ le

${ }^{29}$ EIRAS ROEL, A.: Moderados y cartistas: La «Patuleia y la reacción española: Revista Portuguesa de Hissória XIV (1970), 190-228.

30 Pero en Villa Franca, el pueblo los volvió a elegir, «y en su consecuencia una comisión compuesta de electores de la Provincia, con el vizconde de Sá da Bandeira a la cabeza, ha ido a felicitarlos a la misma estancia en donde se hallaban arrestados por orden de este gobiernom. 732 Gutiérrez de Terán-González Bravo, Lisboa 15 diciembre 1843, AMAE H 1687.

31 «Nao esqueçamos que o conflito armado em Portugal e que se gerara no rencontro de Torres Novas em 1844, teve a cobertura do governo inglês». Tavares Ribeiro, $\mathbf{M}^{\mathbf{a}} \mathbf{M}$.: Portugal e a Revoluçäo de 1848. Coimbra 1990, 55.

32 Cueto había informado al gobierno portugués de la rebelión ocurrida en Alicante, «haciéndole notar que la coincidencia de las tentativas anárquicas que acaban de tener lugar en España y Portugal manifiesta bien claramente las sectetas inteligencias que existen entre los agitadores de ambos paises, y la necesidad cada vez más palpable de que los gabinetes de Madrid y Lisboa estrechen de dia en día sus relaciones de amistad en beneficio de la noble causa del orden". 13 CuetoGonzález Bravo, Lisboa 9 febrero 1844, AMAE H 1687.

3312 Cueto-González Bravo, Lisboa 8 febrero 1844, AMAE H 1687. Leopoldo Augusto de Cueto, marqués de Valmar, acababa de tomar posesión como secretario de la legación española en Lisboa cargo que desempeñó hasta mediados de 1847. Ocasionalmente fue encargado de negocios de esta legación y responsable del consulado general. AMAE Personal $55 n^{\circ} 2373$.

34 .... povo algum teve nunca mais legitimo motivo de queixa do que o Portugal contra o Ministerio Cabral. A Administraçăo dos Cabraes por uma serie de inauditas venalidades e corrupçāo, pelo systema do mais fraudulento patronato, arruinou inteiramente as finanças do Estado, adoptando ao mesmo tempo diversos expedientes a fim de crear empregos para recompensar os sycophantas do seu partidon. Lord J. Bentinck discurso en los Comunes, 14 de junio de 1847, Debates no 
granjearon la hostilidad de la burguesía septembrista y de importantes cartistas entre los que destacaban los seguidores del duque de Palmela, presidente de la Cámara de los Pares y conocido anglófilo ${ }^{35}$. Opuesto a Cabral era también el representante británico en la corte portuguesa, Howard de Walden ${ }^{36}$. Y con ellos y frente a la monarquía constitucional, los miguelistas. Se explica así que esta insurrección, inicialmente localizada en el Minho, adquiriese rápidamente dimensiones nacionales ${ }^{37}$.

\section{LA INSURRECCIÓN DEL MINHO O «MARIA DA FONTE»}

El gobierno presentó dos leyes. Una prohibía los enterramientos en iglesias. $Y$ otra modificaba la contribución rústica fijando un sistema de reparto. Ambas fueron debatidas ampliamente en las Cámaras y los diarios, pero no se informó debidamente a la población. Al entrar en vigor, hubo motines en el norte de Portugal. El más importante tuvo lugar a mediados de abril de 1846 en el término de Vieira do Minho. Su origen, un alboroto de mujeres dirigidas por una joven conocida como María da Fonte, natural de Fonte Arcada, del concejo de Póvoa de Lanhoso ${ }^{38}$. La población se impuso a las tropas enviadas por las

Parlamento britannico, apéndice a OLA 70. Este fue el tono de las intervenciones de los miembros de la oposición británica en el debate parlamentatio sobre la cuestión portuguesa, que tuvo lugar en junio de 1847.

35 Sobre este momento y su eco en Parlamento Británico, la sesión de 11 junio 1847 en la Cámara de los Comunes, y la del 15 junio 1847 en la Cámata de los Lores, $O$ Livro Azul ou Correspondencia relativa aos Negacios de Portugal, Lisboa, 1847. Intervençazo estrangeira, ou documentos bistóricos sobre a intervençāo armada de França, Hespanba e Inglaterra nos Negocios Intertas de Portugal no anno de 1847, prólogo, Oporto 1848.

3635 González Bravo-secretario de Estado, Lisboa 14 septiembre 1844, AMAE H 1687.

37 Las causas de la coalición de partidos contra Costa Cabral y distanciamiento del gobierno británico fueron, entre otras, el Tratado de Comercio y Navegación de 3 de julio 1842 y el de comercio de esclavos de la misma fecha; la legitimidad de la ocupación de los territorios de Ambriz, Cabinda y Molembo en la costa occidental africana, sujetos a la soberanía portuguesa, la negativa a que desembarcase en Lisboa el general Espartero en julio de 1843 y el mal trato dado a Salustiano Olózaga durante su estancia en Portugal en 1844. Hubo también apoyo británico, más o menos explícito, al golpe de Torres Novas. 'TAvares RuBejro, $\mathbf{M}^{\mathfrak{a}}$ M.: Portugal ... , o. c., 49-55.

38 «O parocho de uma freguezia de Vieira recusou enterrar uma creança, sem que na fórma da lei de saude lhe apresentassem licença da authoridade respectiva; a pobre mai, que nāo cinha talvez dez reis para comprar um bocado de păo, com que macasse a fome, quanto mais dinheiro para pagar os exorbitantes emolumentos do bithete de enterro, nem por isso quiz resignar-se a vêr sepultar seu filinho em sitio profano -voltou á carga com grande numero de visinhas suas para proceder á força ao enrerramento - a auchoridade oppoz-se - os maridos, filhos e irmāos vieram em auxilio das mulheres - começou a lucta, travou-se o conflicto entre o povo e o governo; e a lavareda, que se acendera n'um cantinho da provincia do Minho, azeou-se n'um instante por ella todan. Prólogo Intervençāo estrangeira ..., o. C. 
autoridades ${ }^{39}$. Inspirada en una necesidad higiénica, la ley rompía una tradición seculario.

La prohibición de enterrar los cadáveres en los templos y la obligación de pagar impuestos por efectuarlo en los nuevos cementerios suscitaron protestas $^{41}$. En Vieira el rechazo se concentró contra los funcionarios de Hacienda que elaboraban el catastro para fijar las tasas. Las mujeres asaltaron el edificio. Saquearon y quemaron los registros. Su ejemplo se extendío rápidamente a las poblaciones cercanas. Se pidió la expulsión de los Cabral ${ }^{42}$.

Llegó a Lisboa la noticia de que los habitantes de los concejos de Guimarães, Prado y Penela se habían sublevado. Algunos marcharon sobre Braga para atacar el cuartel del Regimiento de Infantería $n^{\circ} 8$. Fueron rechazados tras enconados enfrentamientos el 14 y 15 de abril.

Ante la gravedad de la situación, salió de Lisboa hacia Oporto el día 15 el vapor «Conde de Tojal», con el gobernador civil de Braga, el coronel del Regimiento de Caballería $\mathbf{n}^{\circ} 6$ y el del Regimiento de Cazadores $\mathrm{n}^{\circ} 7$, todos ellos diputados a Cortes. Se encargó al teniente coronel Moniz organizar una columna de 400 infantes y 40 o 50 caballos para controlar el distrito donde se

39 «Rebentou una insurreição á testa da qual se collocou Maria da Fonte, depois de ter levado uma creança morta a igreja, insistindo em que fosse enterrada no cemiterio da freguezia. Os militares appareceram e forem derrotados pela populaça ..... Lord J. Bentinck, intervención en la Cámara de los Comunes, 14 de junio de 1847, Debates no Parlamento britannico, OLA 71. VIEIRA, C. J.: Apontamentos para a História da Revolugāo do Minbo em 1846, Braga 1884. Castelo BRANCo, C.: Maria da Fonte, Oporto 1885. TeIXeIRA DE MACEDO, A.: Traços de Historia Contemporânea. 18461847. Oporto 1880, fixação e revisão de texto, F. Marques da Costa, Lisboa 1984. CYRNE, F.: $A$ patuleia no Alto Minbo. Alguns pormenores da sua bistbria, Viana do Cascelo 1964. RIEGELHAUPT, J.: Camponeses e Estado liberal: a revolta da Maria da Fonte: Studium Generale. Estudos Contemporâneos 23 (Porro 1981) 129-139. CAsTro Feljo, R G. de: Mobilizaţäo rural e urbana na Maria da Fonte: O Liberalismo na Peninsula Ibérica na primeira metade do século XIX, II. Lisboa 1982, 183-193. Hay una amplia bibliografia en NOBRe VARGUES, I.: Insutreiçoes e revoltas em Portugal (1801-1851). Substdios para uma cronologia e bibliografia: Revista de Histótia das Ideias 7 (1985) 501-572. CoImBRA, $\mathrm{M}^{\mathrm{a}}$. N. y AZENHA, $\mathrm{M}^{\mathrm{a}}$ do $\mathrm{R}^{\mathrm{o}}$ : Revoltas e revoluegōes. Catálogo da Exposiģäo bibliográfica: ib. 573-585.

40 En España pasaron casi treinta años hasta que en 1804 se aplicó con rigor la Real Cédula de 9 de diciembre de 1776 de Carlos III sobte la edificación de cementerios. Aquel año y el anterior hubo epidemias, entre las que destacó la fiebre amarilla. Como ejemplo local, VILAR, J. Bta.: Cebegin, señorío santiaguista de los Borbón-Parma (1741-1856), Murcia 1985, 88-89.

41 "O tributo sobre os enterros era absolutamente obnoxio; os parentes de um fallecido deviam apresentar um attestado, pelo qual pagavarn 10 shillings antes de ser enterrado o corpo...». Mr. Osborne, discurso en los Comunes. 11 de junio de 1847, "Debates no Parlamento britannico", apéndice OLA, 41. Sobre lo mismo, vid. Prólogo Intervenşäo estrangeira ...

42 "Ao toque dos sinos a povoação levantava-se em masa - creanças imberbes, mulheres fracas, velhos decrepitos seguiarn os robustos e esforçados - não havia distincção de classe, posição ou côr politica - unia-os a codos o odio commum, a todos o furor ministrava armas: e aos gritos de morram os Cabraes, abaixo as leis de saude e repartição movia-se a provincia em pêso de umas para outras terras depondo as authoridades, que a tinham avexado, substituindo-as por homens bons, queimando as papeletas...». Prólogo Intervenz̧äo estrangeira ..., o. c. 
hallaba la mayor parte de los pueblos sublevados. Otras columnas volantes recorrerían las provincias de Tras-os-Montes, ambas Beiras, Alentejo y Algarve.

Aunque sólo tomaban parte en esos movimientos «individuos del paisanaje» y el móvil principal era «la resistencia al pago de las nuevas contribuciones", convenía a España prestar auxilio al gobierno portugués para teprimir a los rebeldes, impidiendo la aparición de otros focos de descontento ${ }^{43}$.

\section{LA SUBLEVACIÓN PROGRESISTA EN GALICIA}

Ligadas a esos movimientos, la actividad de los revolucionatios y la influencia de la insurrección progresista en Galicia, que duró casi todo el mes de abril de $1846^{44}$. Sus objetivos, imponer el matrimonio de Isabel II con su primo don Enrique de Borbón, su candidato ${ }^{45}$ y la supresión del nuevo sistema tributario, el restablecimiento de la milicia nacional y la libertad de prensa ${ }^{46}$.

Los revolucionarios portugueses y españoles habían convenido en Évora formar partidas que actuarían en España. La labor del general Iriarte, uno de los militares implicados en la insurrección progresista gallega, se había intensificado ${ }^{47}$.

A don Enrique de Borbón, entonces en La Coruña al mando del bergantín «Manzanares», se le ordenó zarpar el 31 de marzo en el «Constitución». Desembarcó en Socoa. Oficialmente iba a Francia con autorización de la Reina para tomar las aguas de los Pirineos en alguno de los balnearios de la región de Pau.

Las juntas de Madrid y Galicia y los centros de Portugal, París y Londres deseaban que el pronunciamiento fuera en La Coruña, pero estalló en Lugo la mañana del 2 de abril14. Favoreció la insurrección la caída del ministerio Nar-

${ }^{43}$ R 358 y 363 González Bravo-Istúriz, 15 y 18 abril 1846, AHN Estado 5412/1. Sobre su etapa como ministro en Lisboa, TAXONERA, L. de: González Bravo y su tiempo (1811-1871), Barcelona 1941, 141-151. Para Francisco Javier Istúriz, presidente del Consejo de ministros desde abril de 1846 hasta enero de 1847, AMAE Personal $140 \mathrm{n}^{\circ} 6831$.

44 Eso opinaba González Bravo. Sobre la insurrección progresista en Galicia, PORTo, J. do: Reseña bistórica de los altimos acontecimientos politicos de Galicia, Madrid 1846. FERNANDEZ DE LOS Ríos, A.: Estudio bistorico de las luchas políticas del siglo XIX, II, Madrid 1880, 149-156.

4s Sobre la cuestión de los matrimonios regios, TERESA PUGA, $\mathbf{M}^{2}:$ El matrimonio de lsabel $I$, Pamplona 1964. Volvemos sobre ello más adelante.

46 CABEZA SÁNCHEZ-ALBORNOZ, S.: Los sucesos de 1848 en Erpaña, Madrid 1981, 17.

47 Informe del comandante general de la provincia de Huelva al capitán general de Andalucia, enviado el 18 de abril. Copia del oficio Istúriz-Sanz, 24 abril 1846, AHN Estado 5412/1.

48 «Un batallón del regimiento de Zamora, que desde la Coruña pasaba a Valladolid, se pronunció en Lugo el día 2 del corriente, en unión con una corta fuerza del Provincial de Gijón a la que sedujo con la falsa noticia de que el general Puig Samper estaba al frente del movimiento. Este digno jefe, para desmentir la voz esparcida por los rebeldes se ofreció a tomar el mando de la columna que contra ellos se disponía a salir de la Coruña; pero noticiosos ésros de los preparativos que se hacian, abandonaron Lugo y se dirigieton a Santiago donde entraron, habiéndoseles unido el 
váez, pero Madrid y Málaga, dos plazas que inicialmente se esperaba que se sumaran a ella, no la secundaron ${ }^{49}$.

Para evitar la colaboración entre los revolucionatios de ambas naciones, el gobierno portugués a través de los ministerios de la Guerra y del Reino, el 8 de abril cursó órdenes terminantes a las autoridades para que, de acuerdo con las españolas, adoptasen las medidas convenientes para destruir las intentonas revolucionarias y detener al ex-general progresista Iriarte ${ }^{50}$.

Urgía una mayor vigilancia sobre los emigrados políticos españoles en Portugal, destinar fuerzas suficientes para impedir el cruce de la frontera por grupos armados que huyesen de la persecución de las autoridades portuguesas y actuar de forma concertada en la frontera ${ }^{51}$. Debería establecerse cuerpos de observación en la de Galicia ${ }^{52}$.

Un decreto del capitán general de Galicia del 4 de abril en La Coruña declaraba el estado de sitio en todo el territorio bajo su mando. Se aplicaría en consejo de guerra a los rebeldes la ley de 17 de abril de $1821^{53}$. José Gutiérrez de la Concha derrotó a Iriarte frente a Astorga y le obligó a huir a Portugal. Ocupó Orense y atacó luego a Solís en Cacheira rindiéndole en San Martín ${ }^{54}$. Fueron fusilados el 26 de abril en El Carral los comandantes Miguel Solís y Cuetos y Víctor Velasco, los capitanes Jacinto Daban, Fermín Mariné, Manuel Ferrer, Ramón José y Llorens, Juan Sánchez, Ignacio de la Infanta, Santiago La Llave, José Márquez, José Martínez y Felipe Valero. El sargento A. Samitier, poco después, en Betanzosss. Los que escaparon, pasaron a Portugal. Entre ellos, Iriarte.

batallón de Provinciales de Zamora que lo guarnecía. También en Villar de Ciervos, pueblo de concrabandistas, froncerizo a Portugal, se ha dado el grito de rebelión y se ha observado en sus inmediaciones un grupo de trescientos hombres armados, capitaneado por el ex-general Iriarte, que parecía dirigirse hacia la Puebla de Sanabria, y no sería de extrañar que en los primeros momentos los amotinados hayan logrado sublevar además alguno que otro pueblo de Galicia...». Vid. esta información previa a las instrucciones ciradas en la nota 51 .

49 A. Fernández de los Ríos, Estrudio bistórico ..., o. c., II, 149. La causa principal de ese fracaso fue la negativa del comandante jefe de Estado Mayor del recién relevado capitán general de Galicia, Puig Samper. Miguel Solís y Cuetos sentía una gran admiración hacia su superior y no estaba dispuesto a detenerlo.

5o Copia traducida de la nota Gomes de Castro-González Bravo, 11 abril, anexo a R 358 González Bravo-Istúriz, 13 abril, AHN Estado 5412/1.

\$1 Minuta instrucciones Istúriz-González Bravo, 11 abril, AHN Estado 5412/1. Vid. también 936 C. di Pietro-Secretario Estado, Lisboa 15 abril 1846, ASV SS 250 (1846) 2 80, en DíAZ DE CERIo, F.: Informes $y$ noticias de las Nuncios en Viena, París y Lisboa sobre la España del siglo XIX (18141846). II: Los Nancios en Lisboa, Roma 1990, 85-86.

$\$ 2$ Urgente 365 González Bravo-Istúriz, 20 abril, AHN Estado 5412/1. Comenta también el posible regreso de Espartero a España, exiliado en Londres.

53 Noticia en 936 C. di Pietro-Secretario Estado, Lisboa, 15 abril 1846, ASV SS 250 (1846) 280.

${ }^{54}$ Fernández de los Ríos, A. Estudio bistórico ..., o. c., II, 154. 943 C. di Pietro-Secrecario Estado, Lisboa 18 abril 1846, ASV SS 250 (1846) 332.

ss Gacta de Madrid 4248 (2 mayo) 1. A. Fernández de los Ríos, Estudio bistórico ..., o. c., II, 155. 


\section{5. ¿UN MOVIMIENTO POPULAR?}

Mientras tanto, la situación segứa agravándose en Portugal. Otras poblaciones, como Barcellos y Ponte de Lima, se unieton a los insurgentes, que atacaron por tercera vez al Regimiento de Infantería $\mathrm{n}^{\circ} 8 \mathrm{de}$ Braga. Eran entre 3000 y 4000 frente a 600 soldados. Fueron rechazados pero hubo numerosos muertos y heridos en ambos bandos.

Costa Cabral informó al Congreso el día 20 de abril sobre la situación en la provincia del Minhos'. Para sofocar la sublevación, pidió la aprobación de dos decretos. El primero suspendía las garantías constitucionales en todo el país hasta lograr la pacificación. El gobierno tendría facultades extraordinarias y discreccionales. El segundo establecía, en todos los distritos declarados en estado excepcional, consejos de guerra para condenar a la pena capital a los autores del delito de sedición. Los rechazó la oposición, pero fueron aprobados tras ser enviados a la Comisión de Legislación y declararse la Cámara en sesión permanente ${ }^{57}$.

Ese mismo día, el ministro de Negocios Eclesiásticos y de Justicia, José da Silva Costa Cabral, hermano del ministro del Reino, marchó a Oporto, capital de la insurrección, con plenos poderes ${ }^{58}$.

El conde de Thomar, título nobiliario de A. B. Costa Cabral desde 1845, calificó la insurrección de septembrista. Detrás de ella, las comisiones provinciales denominadas "filiaes». Las instrucciones venían de la sociedad septembrista denominada «Associação Eleitoral» ${ }^{59}$.

Un sector del gobierno consideraba absolutista el movimiento ${ }^{60}$. Gomes de Castro, ministro de Asuntos Exteriores, comentó a González Bravo que el antiguo general miguelista vizconde de Azenha se había puesto al frente de la sublevación ${ }^{61}$. Había clérigos restauracionistas, entre los que destacaban Casimiro José Vieira, João do Cano, Manuel de Agra y José de Laje. Todos ellos mandaban guerrillas que atacaban a los soldados del gobierno ${ }^{62}$.

\footnotetext{
36 Extracto de su discurso en Noticias Extranjeras. Portugal: Gaceta de Madrid 4244 (28 abril) 2. Crónica Politica. Noticias Extranjeras. Lisboa 21 abril: El Católico 2201 (28 abril) 212.

37 Utgente 365 González Bravo-Istúriz, 20 abril, AHN Estado 5412/1. Texco de los decretos, Crónica Política. Noticias Extranjeras. Lisbaa 21 abril: El Católico 2201 (28 abril) 212.

${ }^{38}$ Las amplias atribuciones concedidas a este miniscro sobre autoridades civiles y militares causaton descontento entre la oficialidad del ejército. 368 González Bravo-Istúriz, 25 abril, AHN Estado 5412/1. Crónica Politica. Noticias Extranjeras. Lisboa 21 abril: El Católico 2201 (28 abril) 212.

9 Utgente 365 González Bravo-Istúriz, 20 abril, AHN Estado 5412/l.

60 «El grito general es por don Miguel; algunos vitorean a la reina absoluta, pidiendo la derogación de las leyes nuevas y proclamando las antiguas». Crónica Politica. Noticias Extranjeras. Lisboa 25 abril: El Católico 2205 (2 mayo) 243.

61 366 González Bravo-Istútiz, 20 abril, AHN Estado 5412/1.

62 "Consta que las guerrillas han quemado todos los papeles de la administración e impresos de Hacienda... Nombraron todas las autoridades; unos daban vivas a don Miguel, otros a S. M. la Reina absoluta, a las leyes de don Juan VI, añadiendo abajo los tributos y el gobiernom. Crónica politica. Noticias Extranjeras. Oporto 30 abril: El Católico 2216 (13 mayo) 332.
} 
Otros negaban a la insurrección cualquier aspecto político. Era un movimiento popular surgido contra la administración cabralista. Quería la nación un gobierno honesto, leyes benéficas, parlamento elegido por el pueblo. $\mathrm{Ni}$ camarillas, ni impuestos insoportables y un poder judicial independiente ${ }^{63}$. "Abaixo a tyrannía, seja o novo grito de guerra" ${ }^{64}$. Era "patente que el descontento público, ocasionado por faltas y abusos de la administración, es uno, y no el menor de (sus) móviles" ${ }^{65}$.

No interesaba al gabinete español el derrocamiento del cabralismo, que contaba con un poderoso aliado en los moderados preocupados por la insurrección de Galicia. Hubo, pues, una permanente cooperación para impermeabilizar la frontera y evitar la unidad entre los revolucionarios de ambos países. Cabral atendió la solicitud de España para desarmar e internar a los insurgentes de Galicia que pasaran a territorio portugués ${ }^{66}$. Dictó órdenes a sus mandos militares de la frontera ${ }^{67}$ y puso tropas bajo mando español ${ }^{68}$.

Las autoridades actuarían combinadas ${ }^{69}$. El capitán general de Galicia, Juan de Villalonga, recomendó que hubiese relaciones frecuentes del comandante de la división expedicionaria, José de la Concha, y de los comandantes generales de las provincias de Orense y Pontevedra, con el comandante general de las fuerzas portuguesas en las provincias limítrofes ${ }^{70}$. No se excluyó que las fuerzas

63 « ...los defectos y la violencia del régimen tributario de este país ha exasperado la miseria pública que había llegado al extremo; $y$ los infelices oprimidos, sin pan y sin recursos, entregados a la desesperación, se han arrojado a coda clase de excesos. Lo absurdo y confuso de la exacción ha llegado al punco de imponer una contribución sobre los muertos, a quienes no se da sepultura sin que aquella se pague. Esto ha producido escenas horribles y violencias escandalosas, fáciles de comprender en un país tan pobrex. Crónica Política. Noticias Extranjeras. Lisbaa 29 abril: El Católico 2208 (5 mayo) 268.

6i Proclama fechada en abril de 1846, AAE MD Portugal 16 62-63.

63 Urgente 365 González Bravo-Istúriz, 20 abril, AHN Estado 5412/1.

66 362 González Bravo-Istúriz, 16 abril, AHN Estado 5412/1. La solicitud de González Bravo à gobierno portugués, fechada en Lisboa el mismo día, ANTT MNE 452.

67 Comunicación del ministro de Guerra a su colega de Asuntos Exteriores, Lisboa 20 de abril. Al día siguiente, éste lo ponía en conocimiento del plenipocenciario español. Copia traducida nota Gomes de Castro-González Bravo, 21 abril, anexo a 366 González Bravo-Istúriz, 22 abril, AHN Estado $5412 / 1$.

68 El comandante general de Braganza puso las fuerzas portuguesas para cubrit la línea fronteriza, unos 400 hombres, a disposición del gobernador de la Puebla de Sanabria. Capitán general de Castilla la Vieja al ministro de Guerra, 19 de abril. Sanz-Istútiz, Madrid 21 abril 1846, AHN Estado 5412/1. Gonzáiez Bravo agradeció a Gomes de Castro la colaboración prestada para sofocar la insurrección de Galicia. González Bravo-Gomes de Castro, 1 mayo 1846, ANTT MNE 452. El embajador enviaba copia de algunos párrafos de los despachos de Istúriz.

69 Istúriz-González Bravo, 23 abril, AHN Estado 5412/1.

${ }^{70}$ Juan de Villalonga-Sanz, 30 abril, inserto en oficio Sanz-lstúriz, 4 mayo, AHN Estado $5412 / 1$.

Hispania, LX/3, núm. 206 (2000) 1001-1046 
traslimitasen la línea fronteriza persiguiendo a los rebeldes de Galicia y Minho ${ }^{71}$

Se buscaba un efecto disuasorio. Juan de Villalonga ordenó al general José de la Concha «que de las fuerzas que tiene a sus órdenes sitúe alguna en puntos fronterizos para que... contribuya al sostenimiento del orden y la tranquilidad en nuestro país» ${ }^{72}$. Se quería también proporcionar al gobierno portugués un argumento para justificar la represión ${ }^{73}$.

Cuando decretó el capitán general de Galicia el bloqueo de sus costas ${ }^{74}$, las autoridades portuguesas cooperaron en el transporte de españoles emigrados tras los sucesos que acabamos de comentar ${ }^{75}$. Ordenaron la detención y devolución, caso de tocar en puertos portugueses, del bergantín de guerra español "Nervión» y la barca de resguardo marítimo "Astuto», que se habían unido a los sublevados en Vigo ${ }^{76}$. Persiguiendo al «Nervión» llegó el 6 de mayo a Lisboa en el vapor de guerra "Vulcano" el brigadier José Fermín Pavía, comandante general de las fuerzas navales que operaban en Galicia. Le ofrecieron

$"$ Istúriz-González Bravo, 25 abril, AHN Estado 5412/1. González Bravo-Gomes de Castro, 1 mayo, ANTT MNE 452. Vid. A. Eiras Roel, Moderados y cartistas ..., o. c., 200. $5412 / 1$.

12 Juan de Villalonga-Sanz, 30 abril, inserto en oficio Sanz-Istúriz, 4 mayo, AHN Estado

${ }^{3}$ *Las noticias que he recibido ... acerca del movimiento revolucionario que ha tenido hugar en Portugal y que parece se va extendiendo hacia Oporto me hace creer sería muy conveniente continuase por ahora situado con aquellas tropas en Tuy, por la fuerza moral que esto daría a las autoridades del gobierno de S. M. F. para sofocar aquel movimiento ...». José de la Concha-Sanz, Vigo 28 abril, inserto en oficio Sanz-Istúriz, Madrid 2 mayo, AHN Estado 5412/1.

74 Texto del decreto fechado en La Coruña el 15 de abril y firmado Juan de Villalonga, Gaceta de Madrid, 4238 (22 abril); en Noticias de Galicia. Ministerio de la Guerra: El Católico 2195 (22 abril) 165 y en British and Foneing State Papers, v. XXXV, London 1860, 860-861. El plenipotenciario briránico en Lisboa ponía en duda canto la legalidad de la medida con arreglo a derecho internacional y su eficacia dada la precariedad de medios del gobierno español. La tensa e interesante correspondencia entre Howard de Walden y González Bravo. 370, 375 y 383 González Bravo-Istúriz, 29 abril, 4 y 8 mayo 1846, AHN Escado 5412/1. Comunicación al gobietno de Lisboa, González Bravo-Gomes de Castro, Lisboa 29 abtil, ANTT MNE 452. El levantamiento del bloqueo de las costas de Galicia, González Bravo-conde de Lavradío, 28 mayo, ib. Acuse de recibo, LavradíoGonzález Bravo, 2 junio 1846, ANTT MNE L' 155.

7519 Bernardo Roiz-Istútiz, Oporto 1 mayo, AHN Estado 5412/1. El expediente de Bernardo Roiz Fuentes, AMAE Personal $205 n^{\circ} 11412$. Vicecónsul en Oporto desde agosto de 1834, ascendió a cónsul de la misma ciudad en julio de 1839.

${ }_{76}$ A bordo del «Nervión" embarcaron los miembros de las juntas de Vigo, Santiago y Pontevedra el día 26 de abril, Gaceta de Madrid, 4247 (1 mayo) 1. Se solitó al gobierno portugués su detención. González Bravo-Gomes de Castro, 4 mayo, ANTT MNE 452 y 377 González BravoIstúriz, 4 mayo, AHN Estado 5412/1. La respuesta fue rápida y afirmativa. Gomes de CastroGonzález Bravo, 5 mayo, ANTT MNE España Lo 155. Copia traducida anexa a 380 González. Bravo-Istúriz, 6 mayo, AHN Estado 5412/1. 
toda clase de facilidades los ministerios de Marina y Asuntos Exteriores ${ }^{77}$. Regresó a Vigo el día 9 al saber que el bergantín, fondeado en Gibraltar, se encontraba ya en poder de España ${ }^{78}$.

No bastó la cooperación entre los dos gobiernos para detener el deterioro de la situación en Portugal. Se extendía e intensificaba la insurrección ${ }^{79}$. La oposición abandonó sus escaños en la Cámara de los Pares el 5 de mayo, porque Costa Cabral había prohibido que se imprimiese en el Diario do Governo los discursos pronunciados en las sesiones parlamentarias, alegando que su publicación podía estimular a los rebeldes ${ }^{80}$. Dos días después, los diputados cabralistas rechazaban por una mayoría de 61 votos contra 15 la discusión de una proposición de la oposición sobre la conveniencia de solicitar de la Reina la destitución del ministerio. No contribuía a calmar los ánimos la detención de las principales voces críticas. Sampaio, director del periódico $A$ Revoluçāo de Septembro, el ex-diputado Leonel Tavares, el ex-ministro de Hacienda, barón da Foscoa, y otros destacados miembros de la oposición fueron arrestados ${ }^{81}$.

Desde el 22 de abril, Silva Cabral había establecido su cuartel general en Oporto. Formó batallones de seguridad pública en la ciudad, en Villanueva de Gaya y Aveiro. Destituyó a las autoridades que se habían unido a los sublevados y se incendiaron muchas de sus casas. Estas decisiones exasperaron más los ánimos contra el gobierno. Mientras, seguían los desórdenes ${ }^{82}$. Cuando llegaron a la capital del Duero noticias de una generalización del conflicto, su guarnición se preparó para un ataque ${ }^{83}$.

La situación se complicaba día a día. La insurrección parecía imparable tras el pronunciamiento de los Algarves, Évora, Vizeu y Tras-os-Montes ${ }^{84}$. Howard

7380 González Bravo-Istútiz, 6 mayo, y 57 cónsul Lisboa-istúriz, 6 mayo 1846, AHN Estado 5412/1. González Bravo-Gomes de Castro, el mismo día, informándole de su llegada, ANTT MNE 452.

7858 Bernardo Roiz-Istúriz, Oporto 9 mayo, ANH Estado 5412/1.

79 Crónica Politica. Noticias Extranjeras. Lisboa 29 abril: El Católico 2209, 2216, 2222 y 2223 $(6,1319$ y $20-21$ de mayo 1846$) 275,332-333,380-381$ y $388-389$.

90 381 González Bravo-Istúriz, 6 mayo, AMAE H 1687.

81386 González Bravo-Istúriz, 9 mayo, AHN Estado 5412/1.

82 «En Monzao un gran número de paisanos armados se dirigieton a la administración del concejo, de donde extrajeron los impresos de contribución y de las leyes sanitarias, quernándolos enseguida en la plaza pública. Después se dirigieron a Valladares, en cuyo punto quemaron la casa de la administración: los capitaneaban el abad de Cabreiros, el alférez de la $3^{\mathrm{a}}$ sección y Joaquín Pereita de Pías. En el concejo de Coura se han repetido iguales escenas, nombrando asimismo autoridades los revoltosos, que se preparaban para atacar la plaza de Melgazon. Crónica Poltitica. Noticias Extranjerasi. Oparto 29 y 30 abril: El Católico 2216 (13 mayo) 332-333.

a3 «En Braga, como en Tras-os-Montes, en Beira y en otros puntos pululan las guerrillas y todo el Portugal demuestra un general descontento... Esta ciudad presenta el aspecto de un campamento, por todas las calles y plazas se ven centinelas, retenes, patrullas y cañones y los artilleros con mechas encendidasw. Crónica Politica. Noticias Extranjeras. Oporto 6 mayo: El Católico 2223 (20-21 mayo) 388.

24 Crónica Política. Noticias Extranjeras. Lisboa, 13 mayo: El Católico 2224 (22 mayo) 397. 
de Walden declaró a Gomes de Castro, ministro de Estado, que su país se opondría a una intervención militar de España ${ }^{85}$. Madrid dispuso que las tropas se emplazasen en la frontera en alerta pero neutrales ${ }^{86}$.

Costa Cabral reconoció la gravedad del levantamiento, pero se mostró convencido de contar con medios para vencerlo. Aseguraba «que las noticias que circulaban acerca del estado del Minho eran deliberadamente exageradas por la oposicion... las guerrillas reunidas junto a Oporto habían sido batidas por la columna (d)el teniente coronel Moniz ... y lo que más embarazo y disgusto le causaba era la conducta hostil de casi todo el cuerpo diplomático y (su) poca decisión". Habían presentado su dimisión el duque de Terceira, presidente del Consejo, y Falcăo, ministro de Marina. No las aceptó la Reina ${ }^{87}$.

Los hechos demostrarían el error de Costa Cabral. Al palacio real llegó una exposición, firmada por el vizconde de Vinhaes, general-comandante del distrito militar de la provincia de Tras-os-Montes, «pidiendo la reforma del sistema tributario y del Reglamento de sanidad y la modificación de la marcha administrativa del gabinete»88. Comunicó previamente a Silva Cabral «que no se batía contra el pueblo sin que antes se representara a la soberana» ${ }^{89}$. Su actitud arrastró a otros jefes militares.

Mientras María II no nombrara un ministerio que mereciera la confianza del pueblo, se suspendía las hostilidades en el norte ${ }^{90}$. Las Juntas de Braga y

ss «La Inglaterra, en virtud de tratados existentes, es quien únicamente tiene privilegio de mandar aquí fuerza armada, cuando ésta es pedida por el gobierno y para combatir a enemigos extranjeros, pero no a los internos». Crónica Politica. Noticias Extranjeras. Lisbaa 15 mayo: El Católico 2224 (22 mayo) 397-398.

86 «....sin permitirles que pisen el territorio portugués, por ningún pretexto. Que si las autoridades del vecino reino pidiesen a V. E. auxilio, no se lo facilite sin expreso mandato de S. M. a quien dará conocimiento de dicha petición por extraordinario .... . Real Orden ministro Guerra al capitán general Castilla la Vieja, Madrid 16 mayo, AHN Estado 5412/1. Mientras el capitán general de Galicia, Juan Villalonga, salía para Orense con tres batallones, el brigadier Calonge se acercaba desde la provincia de Salamanca a Portugal. Crónica Poltitica. Noticias Extranjeras: El Católico 2224 (22 mayo) 398.

87 392 González Bravo-Istúriz, 16 mayo, AHN Estado 5412/1.

g8 393 González Bravo-Istúriz, 18 mayo, AHN Estado 5412/1. Cúnica Politica. Noticiass Extranjeras. Fronteras de Portugal en Galicia, 15 mayo y Crónica Politica. Noticiass Extranjeras. Lisboa 18 mayo: El Católico 2223 y 2227 (20-21 y 27 mayo) 389 y 421-422.

89 «... es un hecho que las autoridades civiles y militares de Braga, de acuerdo con los comandantes de operaciones han resuelto cesar las hostilidades contra el pueblo, y habiendo éste aceptado aquella propuesta, de conformidad unos y otros representaron a la Reina Doña María II manifestando el verdadero estado del pás y pidiendo las providencias para evitar el mal que les afligew. Cónica Polftica. Noticias Extranjeras. Oporto, 17 mayo: El Católico 2229 (27 mayo) 437-438.

90 «Los generales Valongo y Vinhaes con sus tropas, marcharon sobre Villa Real para atacar a los revoltosos, pero la fuerza de aquellos era tan considerable, que tuvieron que tetroceder, y principalmente porque los soldados decían que no querían batirse con sus hermanos, aludiendo al pueblo. En vista de esto, los dos generales cabralistas hicieton una especie de convenio, suspendiendo las hostilidades hasta que S. M. nombre un ministerio que cuente con la opinión pública, lo cual deberá 
Villa Real habían declarado ilegales las Cortes portuguesas. Al lado de la corte y de las logias cabralistas sólo quedaban las guarniciones de Oporto y Lisboa. Ante estas dificultades, Silva Cabral se trasladó a Lisboa, dejando en Oporto una junta conservadora protegida por los jefes de las tropas'.

Mientras se esperaba la decisión de la Reina sobre la formación o no de otro ministerio, el vizconde de Fonte Nova, al mando de las fuerzas de la ciudad, conservó el orden impidiendo la entrada de los rebeldes. El 17 de mayo firmó dos proclamas, una dirigida a los ciudadanos y otra a los soldados. En la primera afirmaba que las tropas de la guarnición aguardarían la respuesta de María II a las representaciones que había recibido y obedecerían su resolución. Amenazó a quienes intentasen perturbar el orden público. En la segunda, arengaba a las tropas para que mantuvieran «el sosiego público»92.

Previamente Silva Cabral había dirigido una proclama a los habitantes del norte para tranquilizarlos. Llamaba a superar la anarquía y trabajar por la paz y la concordia. Había que poner fin al derramamiento de sangre. En la Carta estaba la solución. La Reina haría justicia a las reclamaciones del pueblo e implantaría las reformas necesarias. Solicitaba tiempo para ponerlas en marcha ${ }^{93}$. No se creyó esa promesa. Una declaración, fechada el 15 mayo e impresa «na Typ. Nacional Patriotica" anunciaba que los gastos de la guerra se pagarían con los bienes de los «ministros que oprimen (a la Nación), de los consejeros... que han dilapidado sus rentas; del parlamento que ha decretado esas leyes sanguinarias y desastrosas y con un descuento en la dotación de quien los sanciona»94.

Tras su llegada a Lisboa en el vapor de guerra «Duque de Oporto», José da Silva Cabral informó sobre la gravedad de la situación. Celebrado Consejo de Ministros ese mismo día, 17 de mayo, contra la opinión del conde de Thomar pero ante la decidida actitud de su presidente, duque de Terceira, dimitió el gabinete. María II encargó la formación de uno nuevo al conde de Villa Real, destacado cabralista95. Se descartó esta salida a la crisis tras una reunión en el

verificatse en el término de seis días». Crónica Politica._Noticias Extranjeras. Lisbaa 18 mayo: El Católico 2227 ( 25 mayo) 421.

${ }^{11}$ Crónica Politica. Noticias Extranjeras. Portugal: El Católico 2227 (25 mayo) 422.

${ }_{92}$ Crónica Politica. Noticias Extranjeras. Oporto 18 mayo: El Católico 2229 (27 mayo) 439, citando al Boletín Oficial de Oporto del 18 mayo.

${ }_{93}$ Texto en Cnónica Politica. Noticias Extranjeras: El Católico 2227 (25 mayo) 423. Traducción francesa y réplica a Silva Cabral, a quien se tachaba de traición e infamia, AAE MD Portugal 16 66-68.

94 "Tudo ha de ser respeitado, menos o crime; tudo ha de ser garantido, menos o roubow, AAE MD Portugal 1669.

95393 González Bravo-Istúriz, 18 mayo. El gobierno español ordenó a su representante en Lisboa que observase «la más perfecta neucralidad en una cuestión exclusivamente del dominio y voluntad del monarca», minuca Istúriz-González Bravo, 23 mayo, AHN Estado 5412/1. 
palacio de Belem, a la que asistieron los Reyes, los ministros propuestos del nuevo gobierno y el duque de Terceira ${ }^{96}$.

\section{LAS REClaMaCIONES AL GABINETE DE PALMELA}

Hubo de recurrir la Reina al duque de Palmela, que acudió a palacio el 19 de mayo y se dirigió desde allí a la secretaría de Guerra para entrevistarse con el duque de Terceira y ser informado del estado del país ${ }^{97}$.

Mientras, el conde de Thomar y su hermano se retiraron al cuartel de la guardia municipal. El odio contra ellos en el partido llamado al poder los ponía en peligro, si estallaba en Lisboa una revuelta popular. González Bravo les ofreció asilo en la legación española y realizó gestiones para proteger sus vidas ${ }^{8}$. Los Cabral se presentaron en la sede diplomática española el 20 de mayo. Aún duraba esa noche el griterío de los tumultos populares en las plazas del Terreiro do Paço y Cais do Sodré.

Corrió la noticia de que ese mismo día habían sido firmados varios reales decretos admitiendo la dimisión presentada por Costa Cabral y sus compañeros y nombrando un nuevo gobierno con el duque de Palmela como ministro y secretario de Estado de Negocios del Reino con la presidencia del Consejo de Ministros. Interinamente se encargaría también de las carteras de Hacienda, Negocios Eclesiásticos y Justicia. El resto del gabinete lo formaban: el duque de Terceira, en Guerra, y Marina y Ultramar, y provisionalmente, Asuntos Exteriores durante la ausencia del marqués de Saldanha ${ }^{99}$

${ }^{96}$ La reunión tuvo lugar en la noche del 18 de mayo y la combinación ministerial propuesta fue la siguiente: el conde de Villa Real, Presidencia del Consejo y Guerra; Rodrigo de Fonseca, Asuntos Exteriores; Silva Carvalho, Justicia; Tavares Proenza, Reino; Carvalho, Marina; Florido Ferraz, Hacienda, 394 González Bravo-Istúriz, 20 mayo, AHN Estado 5412/1. Crónica Política. Noticias Extranjeras. Lisbaa 18 mayo y Crónica Politica. Noticias Extranjeras. Lisboa 20 mayo: El Católico 2227 y 2229 ( 25 y 27 mayo) $421-422$ y 438.

97 Crónica Politica. Noticias Extranjeras. Lisbaa 20 mayo: El Católico 2229 (27 mayo) 438.

98 Envió al agregado de la legación, Francisco Figueras, a entreviscarse con el capicán general de Galicia. Se necesitaba cuanto antes en el puerto de Lisboa un buque de guerra español, donde pudieran refugiarse el conde de Thomar y su familia. 394 González Bravo-Istúriz, 20 mayo. La oferta de asilo a los hermanos Cabral y sus familias y la pecición realizada al capitán general de Galicia fueron aprobadas por el gobierno de Madrid. Cifra Iscútiz-González Bravo, 31 mayo, AHN Estado 5412/1.

99 Este ajuste ministerial fue publicado por el Diario do Governo, I18 (Lisboa 21 mayo) 563. Crónica Politica. Noticias Extranjeras. Portugal: El Católico 2232 (30 mayo) 460. En el informe de González Bravo un día anres de esta publicación, se decía que el conde de Tojal se encargaría de Hacienda; Souza Azevedo, de Justicia y aún no había ministro asignado para la Marina. Se malogró debido a las presiones. 394 y 395 González Bravo-Istúriz, los dos del 25 mayo, AHN Estado $5412 / 1$. 
Contra González Bravo se desvió parte de la animadversión revolucionaria ${ }^{100}$. Hubo avisos de atentados a la sede de la legación. Pidió al comandante de la guardia municipal, amigo de Costa Cabral, 18 fusiles con su correspondiente munición y dirigió una dura nota a Palmela, previniéndole «que, ya advertido el gobierno de S. M. Fma., como lo está por la presente nota, del riesgo a que podría estar expuesta esta Legación en el caso de un motín popular, el Gobierno de S. M. la Reina, mi Señora, miraría como un atentado, digno de reparación inmediata, cualquiera tentativa que se encaminase a violar la inmunidad de su representación en esta Corte, inmunidad que la fuerza pública tiene obligación de hacer respetar» ${ }^{101}$. Palmela le ofreció garantías ${ }^{102}$.

Ante el temor de que algún grupo de exaltados intentase apoderarse por la fuerza de los dos ex-ministros, González Bravo y el conde de Thomar decidieron que éste y su hermano se trasladaran al bergantín de guerra francés «Le Cygne». Allí permanecerían hasta la llegada del paquete inglés "Pachá» o del buque de guerra enviado por el gobierno español. Así se hizo el 23 de mayo ${ }^{103}$. Al día siguiente fueron trasbordados al «Pachá» y salieron hacia Cádiz.

El ministerio del duque de Palmela, dominado por él y el duque de Terceira, dada la ausencia del marqués de Saldanha, entonces ministro plenipotenciario en Bruselas, era provisional. Constituido el 20 de mayo, desaparecía a los 6 días ${ }^{104}$. Intentó normalizar la vida portuguesa. El 25 de mayo Palmela dirigió una circular desde el ministerio del Reino al gobernador civil de Oporto y a todas las autoridades administrativas de Portugal, realizando un balance de los primeros pasos dados. Su objetivo, restaurar «la tranquilidad pública, sin la cual no hay sociedad posible»10s.

El día 21 de mayo, María II sancionó un manifiesto gubernamental anunciando la abolición de las leyes de Salud Pública y de la Reforma del Sistema Tributario. Eran justos los motivos de la insurrección y se concedía libertad de

100 Vid. una proclama en anexo 2 a 395 González Bravo-Istúriz, 25 mayo, AHN Estado $5412 / 1$.

101 González Bravo-Palmela, 22 mayo, ANTT MNE 452 y copia, anexo 3 a 395 González Bravo-Istútiz, 25 mayo, AHN Estado $5412 / 1$.

${ }^{103}$ Traducción nota confidencial Palmela-González Bravo, 23 mayo 1846, anexo 4 a 395 González Bravo a Istúriz, 25 mayo, AHN Estado 5412/

${ }_{103}$ De acuerdo con el comandante de la Guardia Municipal, Mascarenhas, y el comandante del batallón $\mathbf{n}^{\circ}$ 2, de servicio en el Tetreiro do Paço, fueron conducidos por González Bravo al muelle de las Columnas. Y desde alli, en un bote armado, del bergantín francés. 395 González BravoIstúriz, 25 mayo, AHN Estado 5412/1. Sobre la salida de los Cabral hacia Cádiz y actitud de González Bravo, Crónica Politica. Noticias Extranjerass. Portugal: El Católico 2234 y 2242 (2 y 10-1 1 junio) 479 y 543 .

${ }^{104} \mathrm{El}$ representante español ya apuntaba que «no podía satisfacer las exigencias revolucionarias», 395 Gonzâlez Bravo-Istúriz, 25 mayo, AHN Estado 5412/1.

${ }^{105}$ Crónica Politica. Noticias Extranjeras. Portugal: El Católico 2240 (8 junio) 525.526. Las medidas más importantes adoptadas, Howard de Walden-conde de Aberdeen, 28 mayo, apéndice OLA 351.

Hispania, L.X/3, ním. 206 (2000) 1001-1046 
prensa, exigiendo a la vez el restablecimiento del orden y el respeto a las leyes. Se administraría con rigor los presupuestos. Quedarían satisfechas reclamaciones como la convocatoria de Cortes ${ }^{106}$.

El mismo día se firmaron también dos decretos, publicados en el Diario do Governo de Lisboa del día 23. Uno, suspendiendo el de 26 de septiembre de 1845 que reorganizó la contribución de salud pública. El segundo, dando por concluida la sesión ordinaria de las Cámaras de $1846^{107}$.

Otro decreto del 22 de mayo anulaba las disposiciones de la ley de 19 de abril de 1845, volviendo a la legislación anterior sobre contribuciones. Al día siguiente, otro Real decreto disolvía la Cámara de los Diputados, convocando con carácter extraordinatio las Cortes Generales para el 1 de septiembre ${ }^{108}$.

El marqués de Loulé, el conde das Antas, de Lavradío, de Lumiares, de Melo, el vizconde de Sá da Bandeira, Almeida Garret, Fonseca Magalhaes y Joaquim Antonio de Aguiar, entre otros, dirigieron una representación a la Reina el 23 de mayo. Este grupo de pares y diputados justificaba la actitud del pueblo. Solicitaban a la Corona «una representación nacional verdadera y libre; la suspensión inmediata (de la existente), la revocación oportuna de las leyes manifiestamente contrarias a la Carta y opresivas al pueblo; la anulación de todos los actos gubernativos que pecan de los mismos vicios; la autoridad pública y fuerza nacional depositadas en manos de hombres probos, no manchados con la sangre del pueblo, y que tengan dadas pruebas de que no son capaces de oprimirle y de faltar a V. M.»109.

Su contenido coincidía con las proclamas de otras Juntas. La fórmula más empleada era: Carta, Reina, disolución de las Cámaras, elección de otras, dimisión del ministerio, efectiva organización de la Milicia Nacional, revocación del nuevo sistema tributario ${ }^{110}$.

Transmitieron al duque de Palmela esta representación y le ofrecieron su colaboración. Como condiciones para aceptar un ministerio nuevo, que sus integrantes, "extraños a los ertores y faltas de la administración pasada, y fieles a los principios constitucionales, puedan dar garantías de libertad y de verdadero orden al pais, la enmienda de los abusos, y las reformas económicas y ad-

106 El manifiesto en el Diario do Governo 119 (22 mayo) 567. También como anexo 1 a 395 González Bravo-Istúriz, 25 mayo, AHN Estado 5412/1 y anexo a Howard de Walden-conde de Aberdeen, 28 mayo, apéndice OLA 353. Texto castellano en Crónica Politica. Noticias Extranjeras. Portugal: El Católico 2231 (29 mayo) 452 y texto francés en AAE MD Portugal 16 72-73.

${ }_{107}$ Crónica Politica. Noticias Extranjeras. Portugal: El Católico 2232 (30 mayo) 460.

${ }^{108}$ Crónica Politica. Noticias Extranjeras. Lisboa 24 mayo: El Católico 2234 (2 junio) 477.

109 El documento en Crónica Politica. Noticias Extranjeras. Portugal: El Católico 2240 (8 junio) 524-525.

110 Crónica Politica. Noticias Extranjeras: El Católico 2234 (2 junio) 479.

Hispania, LX/3, núm. 206 (2000) 1001-1046 
ministrativas que son la imperiosa necesidad de la situación actual»"11. Excluían así al duque de Terceira, corresponsable de todos los males que sufría el país ${ }^{112}$.

\section{UNA SALIDA POLÍTICA LIBERAL}

Habría que dar paso a «liberales sin tacha», pedía en Madrid El Clamor. Pocos dias después, el 26 de mayo, se conoció la organización de un nuevo gabinete: el duque de Palmela, Presidente del Consejo y ministro de Hacienda; Luiz da Silva Mousinho de Albuquerque, ministro de los Negocios del Reino; Joaquim Filipe de Souré, de Negocios Eclesiásticos y de Justicia; el marqués de Saldanha, de Guerra; el coronel José Jorge Loureiro, de Marina y Ultramar, e interinamente de la Guerra hasta la llegada del anterior; el conde de Lavradío, de Asuntos Exteriores ${ }^{113}$.

Habían triunfado las presiones sobre la Reina. Souré, ministro de Negocios Eclesiásticos y de Justicia, era un apasionado septembrista. Mousinho de Albuquerque y el conde de Lavradío se resistían a aceptar sus cargos mientras permaneciese en el gabinete el duque de Terceira ${ }^{114}$ a quien censuraban también los Cabral en un manifiesto publicado el 28 de mayo en el Comercio de Cádiz. Estos últimos lo acusaron de no haber actuado con energía ante la revolución, de haber sido la causa de la dimisión del ministerio del que formaban parte y de haberse unido a Palmela dispuesto a sacrificarlos «en satisfacción del partido de la revolución». Lo hacían responsable de su exilio ${ }^{115}$.

Pero ni la despedida de Terceira ni las concesiones regias sirvieron para detener la rebelión. El nuevo ministro del Reino, Luis da Silva Mousinho de Albuquerque, en el programa, enviado mediante circular a todos los gobernado-

ii' Crónica Poltitica. Noticias Extranjeras. Pontugal: El Católico 2240 (8 junio) 524, citando A Revoluçäo de Septembro.

112 «El gabinece Patmela ha nombrado jefes políticos de casi todos los puntos del reino a los que se han puesto al frente de los pronunciamientos o merecen la confianza pública; pero eso no basta ya y será insuficiente cuanto se haga para calmar la ansiedad pública, mientras no elija doña María de la Gloria un ministerio compuesto de liberales sin tacha alguna, exonerando a Terceira, que con el mayor escándalo está todavía en el poder, a pesar de haber sido el jefe del gabinete Costa-Cabral. No se puede concebir cómo el duque de Terceira tiene el atrevimiento, la inaudita osadía de continuar figurando en un ministerio cuyo principal objeto es destruir todos los males que él mismo ha hecho al país durante seis años asociado a los Cabrales». Crónica Poltitica. Noticias Extranjetas. Lisboa 25 mayo: El Católico 2234 (2 junio) 478.

113 Decreto exonerando a Palmela de los ministerios de Reino y Justicia, ANTT MNE 402 y Lo 77. 399 González Bravo-Istútiz, Lisboa 27 mayo, AHN Estado 5412/1. Como anexo, el suplemento al Diario do Governo 122 (Lisboa 26 de mayo) con la lista de ministros anotando al margen datos sobre la personalidad de cada uno. Crónica Política. Noticias Extranjeras. Lisboa 25 mayo: El Católico 2234 (Madrid 2 junio) 478.

114399 González Bravo-Istúriz, 27 mayo, AHN Estado 5412/1.

IIs El manifiesto, firmado el 27 de mayo, explicaba los motivos de su salida de Portugal. Crónica Polltica. Noticias Extranjeras. Portugal: El Católico 2234 (2 junio) 479-480. 
res civiles, valoraba los logros obtenidos en el Movimiento del Minho. María II había decidido acabar con los males públicos y contentar los justos deseos de la nación. Como pruebas, la elección de personas conocidas por su sincero servicio a la Corona y al pueblo, la disolución del parlamento y elección de uno nuevo definiendo en un decreto sus facultades. Puesto que la Reina había visto en el levantamiento «la expresión de las verdaderas necesidades de los pueblos», sobraban las armas. Había sido oída ya la voluntad nacional. Con una masa en armas y en medio de una agitación convulsiva, no podían abrirse las urnas. Había que conseguir que las elecciones fuesen libres ${ }^{116}$.

Un sector de la prensa liberal pedía, en cambio, el armamento de la Milicia Nacional y aconsejaba a los sublevados que no depusiesen las armas y llevasen el movimiento adelante hasta el triunfo completo de la revolución ${ }^{117}$.

Así las cosas, el nuevo gabinete lusitano hacía una política de concesiones a la revolución manteniendo sus buenas relaciones con España, según el ministro de Negocios Extranjeros, conde de Lavradío. Siguiendo las instrucciones recibidas de Madrid, González Bravo respondió que España guardaría la más estricta neutralidad. Se conformaba con que se vigilara a los emigrados políticos españoles ${ }^{118}$.

La política de concesiones pretendía recuperar la normalidad necesaria, sobre todo, para resolver la caótica situación financiera en que se hallaba el gobierno lusitano ${ }^{119}$. No podía contarse con el producto de las contribuciones, que el pueblo se negaba a pagar, ni con los recursos del crédito, seriamente dañado. "La Confianza Nacional», una compañía privada, había otorgado préstamos al gobierno, pero, ante el temor de sus impositores que acudieron a reti-

116 «Portanto, sem o desarmamento immediato não póde a nação chegar ao fín sagrado, a que aspirou, - isto é - a uma representação nacional verdadeira, sincera, unico remedio aos males publicos nos Governos Representativos", Circular aos governadores civis dos differentes districtos, Lisboa 27 mayo, I anexo a Howard de Walden-conde de Aberdeen, Lisboa 28 mayo, apéndice a OLA 351352. Texto castellano en Crónica Polltica. Naticias Extranjeras. Lisboa 27 mayo: El Católico 2242 (1011 junio) 541-542 y traducción francesa, AAE MD Portugal 16 90-91.

i1 «Vimos sumir-se a lei das contribuções de repartição e de saude, vimos disolvida a camara dos deputados, e nomeada uma commissão para fazer uma lei de eleiçōes. Muito bem! Applaudimos tudo isso. Mais o povo quer mais - que a revoluçāo legalisada, e nao morta, quer garantias de duraçāo.

Antes de mandar dispersar as massas, porque năo organisa o ministerio as forças nacionaes?. Pois foram até agora elemento de ordem, e receia-se que o sejam agora de anarchia?. Foram patriotas para constituirem o novo poder, e serão desordeiros depois disso?.

A administraçāo odiada cahiu, mas os seus elementos estāo vivos, os seus instrumentos ainda nāo foram quebrados. A força bruta, a inimiga do povo, está nas māos dos mesmos chefes, desses que juraram morrer ao lado de Costa Cabral, e que guardam em seu peito uma raiva concentrada ao povo, a quem honram com o nome de canalla!». A Revolugäo de Septembro, 1512 (Lisboa 29 mayo) anexo a 403 González Bravo-Istúriz, 29 mayo, AHN Estado 5412/1.

1 t8 Encuentro en la primera recepción oficial ofrecida al cuexpo diplomático. 402 González Bravo-Istúriz, 28 mayo, y minuta con instrucciones de Istúriz, 23 mayo, AHN Estado 5412/1.

119 Sobre la situación financiera, vid. GOMES DA SILva SANCHES, J. O verdadeiro estado da fazenda pública en Mato de 1846, Lisboa 1848. 
rar sus depósitos, se vió obligada a solicitar del ministerio una autorización para demorar sus pagos durante tres meses o que éste declarase deuda del Estado la masa de capitales prestada. Fué preciso reunir al Consejo de Estado el 29 de mayo para buscar solución a este problema ${ }^{120}$. El Banco de Lisboa suspendió pagos. En Oporto causaba pánico la caótica situación comercial ${ }^{121}$.

Siguiendo el programa anunciado, el 29 de mayo firmaron un decreto la Reina y todos los ministros, concediendo amnistía general a cuantos participaron en el movimiento revolucionario de Torres Novas en 1844:22. La medida implicaba el retorno a Portugal del coronel César de Vasconcellos y otros offciales confinados en el depósito militar de Toledo.

Para consolidar lo conseguido, empezaron a producirse destituciones en los puestos clave del ejército. Las armas no podían estar bajo el mando de oficiales afiliados a las logias masónicas de las que Costa Cabral era gran maestre ${ }^{123}$. Un decreto del 31 de mayo reorganizaba la Milicia Nacional ${ }^{124}$. Se nombró dos comisiones para la reforma en el ejército.

El gobernador civil de Oporto, vizconde de Beire, fiel al programa del nuevo ministerio, publicó una proclama. El balance de los logros obtenidos por la revolución era altamente positivo. Por eso invitaba a los sublevados a volver a sus casas ${ }^{125}$. Así lo empezaron a hacer. La prensa más radical lo aprobaba. Muchas fuerzas populares se sometían a la autoridad del poder central. Las Juntas gubernativas iban autodisolviéndose. Se inició la normalización ${ }^{126}$.

\section{LA SITUACIÓN DE LOS EXILIADOS ESPAÑOLES}

Empezaba a tener éxito la política de concesiones, duramente criticada por algunos sectores de opinión en España. Mal síntoma que se hubiera puesto el gobierno al frente de la revolución. Los decretos publicados desde su llegada al poder parecían una competición con la insurrección en la que el ministerio

\footnotetext{
120403 González Bravo-Istútiz, 29 mayo, AHN Estado 5412/1. Crónica Poltitica. Noticias Extranjeras. Portugal: El Católico 2238 (6 junio) 508.

12i Crónica Politica. Noticias Extranjeras. Lisboa, 3 junio: El Católico 2242 (10-1 1 junio) 543.

122 L o publicó el Diario do Governo el 30 de mayo, texto Crónica Politica. Noticias Extranjeras. Portagal: El Católico, 2242 (10-11 junio) 542.

${ }_{123}$ Crónica Politica. Noticias Extranjeras. Lisboa, 30 mayo: El Católico 2241 (9 junio) 533.

124 Publicado en el Diario do Governo del 1 de junio, Crónica Politica. Noticias Extranjeras. Lisboa, 30 mayo: El Católico 2241 (9 junio) 533-534.

${ }_{125}$ Texto fechado el 31 de mayo en Crónica política. Noticias Extranjeras. Oporto, 1 junio: El Católico 2242 (10-11 junio) 541 .

126416 González Bravo-Istúriz, 9 junio, AHN Estado 5412/1. Contiene como anexo el $2^{\circ}$ suplemento al Diario do Governo 132 (Lisboa 7 de junio) con oficios recibidos del vizconde de Beire, gobernador civil de Oporto, del día 6 . Se había pacificado los distritos de Oporto, Aveiro y la provincia de Tras-os-Montes. Cronica Politica. Noticias Extranjeras. Portugal: El Católico 2241 y 22429 y $10-11$ de junio) 533 y 541 y 2246 y 2247 ( 15 y 16 junio) 572 y 581.
}

Hispania, LX/3, núm. 206 (2000) 1001-1046 
apostaba a llegar más pronto a lo que la primeta proponía. La disolución de las Cámaras y la elección de otras en esos momentos de pasión llevaría a ellas a miguelistas y ultraprogresistas.

Preocupaban las reformas anunciadas. La de la Carta acabaría con la cámara de los Pares. Armar la Guardia Nacional consolidaría una permanente agitación, tal como sucedió en 1837 y 1838 . A estas medidas se sumaban otras como abolir leyes votadas por las Cortes, privar al Consejo de Estado de sus atribuciones administrativas, el nombramiento de los jefes de las Juntas para gobernadores civiles de los mismos distritos donde gobernaban y la destitución de los jefes militares fieles a la causa del orden. Había, pues, una especie de emulación para demostrar "quién era más revolucionario, si el gobierno o la misma revolución»127.

Todo esto afectaba a las buenas relaciones con el gobierno de Madrid. Aprobada la conducta de González Bravo durante la crisis, Istúriz le comunicó que quedaban en Lisboa a sus órdenes el vapor "Vulcano" y la fragata «Isabel II». Si fuera necesario, se pondrían a disposición de María II y su familia, así como de los súbditos españoles que lo solicitasen. España era neutral. Estaba dispuesta a estudiar una posible demanda de Portugal para sofocar la rebelión, si, como contrapartida, se mostraba su gobierno firme en el control de los emigrados políticos españoles. No se toletaría que Portugal se convirtiese en base de operaciones. Para impedirlo, no se descartaba la traslimitación ${ }^{128}$. Se había cursado instrucciones precisas a los capitanes generales de los distritos limítrofes con Portugal ${ }^{129}$. Se redobló la vigilancia para evitar que la situación al otro lado de la frontera animase a los revolucionarios españoles 130 .

A pesar de las órdenes expresas recibidas para que los oficiales emigrados de España que se encontraban en Oporto se trasladasen a Peniche ${ }^{131}$, crecía la $^{2}$ tensión entre los dos países. Entre los motivos, los movimientos de tropas es-

\footnotetext{
127 Crónica Política. Noticias Extranjeras. Portugal: El Católico 2244 (13 junio) 556.

128 «Este y no otro objeto ha tenido a la mira el gobierno de S. M. al ordenar ciertos movimientos de cropas con dirección a la frontera». Cifra minuta Istúriz-González Bravo, 31 mayo, AHN Estado $5412 / 1$.

129 Habria que adoptar «cuantas medidas considere oportunas para que la frontera del discrito de su cargo con el vecino Reino de Portugal esté guardada y vigilada compecentemente, dirigiendo a las autoridades portuguesas de la raya las comunicaciones preventivas y oportunas para que sepan que, si permiten que los refugiados españoles se acerquen a la misma, serán rechazados e incernados por la fuerza sin miramiento a límices ni a consideraciones de ningún género, porque la Nación Española está dispuesta a hacerse resperar a toda costa». Minuta reservada del ministerio de Guerracapitanes generales de Galicia, Castilla la Vieja, Extremadura y Andalucía, Madrid 30 mayo. Las comunicaciones para su ejecución, unstrucciones a los comandantes de las fuerzas situadas en la frontera de Portugal, con motivo de la actitud hostil de los portugueses revolucionarios que se hallan en las inmediaciones», AHN Estado 5412/1.

${ }^{130}$ Minuta circular reservada del ministerio de la Guerra-capitanes generales y comandante general del Campo de Gibraltar, 30 mayo, AHN Estado 5412/1.

${ }^{131}$ Crónica Politica. Noticias Extranjeras. Portugal. Oporto, 30 mayo: El Católico 2242 (10-11 junio) 541 .
} 
pañolas en la frontera ante la amenaza de incursiones de revolucionarios portugueses o de exiliados políticos españoles, la actitud española durante la revolución del Minho, el trato dado a Costa Cabral en Cádiz y el problema planteado con más de un centenar de rebeldes capturados tras los sucesos de Galicia que, al ser trasladados desde España a Cuba, se apoderaron del barco y se dirigieron a Portugal donde fueron acogidos como refugiados políticos, no como desertores, pese a la gestión de la legación diplomática española en Lisboa ${ }^{132}$.

Se temía también una intervención militar española al amparo del supuesto carácter miguelista de la insurrección ${ }^{133}$. El nuncio en Lisboa daba por cierto que la habría solicitado González Bravo a Madrid ${ }^{134}$, quien, en nota fechada el 6 de junio, transmitió la resolución de su gobierno de rechazar toda tentativa encaminada a perturbar la tranquilidad del territorio español, aunque se abstuvo de mencionar el propósito de traslimitar «hasta tanto que den lugar a ello el descuido o la connivencia del gobierno portugués» ${ }^{135}$. Reclamó que se internara y custodiara en un depósito militar a los emigrados residentes cerca de la frontera de Galicia y a los que habían salido de Peniche. El gobierno portugués aceptó pocos días después la responsabilidad de vigilar a los emigrados españoles. Deseaba relaciones de amistad con España ${ }^{136}$.

Esta situación permitió el 15 de junio salir de Lisboa para Ferrol al «Vulcano» 137. Mientras, el marqués de Saldanha, nombrado ministro de la Guerra, rechazó el encargo. Los Reyes pusieron todo su empeño para que rectificara su decisión ${ }^{138}$.

t32 Aspectos recogidos por el nuncio de Lisboa, que concluía: «Tutto ciò non concorre certamente a rinnodare gli amichevoli vincoli fra la Spagna ed il Portogallo». 1013 C. di PietroSecretario Estado, 24 mayo, ASV SS 250 (1846) 3100.

${ }^{133}$ A Revoluçāo de Septembro, 1512 (Lisboa 29 mayo 1846), anexo a 403 González Bravo-Istúriz, 29 mayo, AHN Estado 5412/1. Cńnica Poltica. Noticias Extranjeras. Portugal. Lisboa, 30 mayo: E| Católico, 2237 ( 5 junio) 500.

134 «Se ne dava per motivo la conservazione della dinastia, ch'era minacciata da un rivolta in fa-

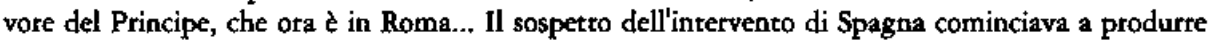
disgusto nel popolom. 1021 C. di Pietro-Secretario Estado, Lisboa 30 mayo 1846, ASV SS 250 (1846) 384 .

${ }^{135}$ González Bravo-Lavradio, 6 junio, ANTT MNE 452. Informe al ministro de Estado, cifra 414 González Bravo-Istúriz, 9 junio, AHN Estado 5412/1.

${ }^{139}$ Lavradio-González Bravo, 9 junio, ANTT MNE Lํ 155. Comunicación a Madrid, 417 González Bravo-Istúriz, 12 junio, AHN 5412/1.

137419 González Bravo-Istúriz, 15 junio, y 65 cónsul Lisboa-Istúriz, 16 junio, AHN Estado $5412 / 1$.

138 «SS. MM. confian en que su presencia en el gabinete será un estorbo a la marcha de la revolución, $y$ han dispuesto que se den algunos pasos para decidirle a cambiar de opinión. Se asegura que $\mathbf{S}$. A. el duque Fernando, padre del rey, que salió de esta Corte el día 13 en compañía de los duques reinantes de Sajonia-Coburgo Gotha, va encargado de persuadir al marqués de Saldanha, que aún se halla en Bruselas, de la conveniencia de que acepte el ministerio en las presentes circunstancias». 420 González Bravo-Istúriz, 17 junio, AHN Estado 5412/1. 
El conde das Antas se hallaba de acuerdo con algunos clubes revolucionarios enemigos del gabinete. Al creer que le faltaba el apoyo del conde, el ministerio dimitió el día 20 de junio. María II no la aceptó y llamó a Das Antas que le ofreció garantías de que defendería sus prerrogativas como Reina ${ }^{139}$.

Entretanto, González Bravo negaba al gobierno portugués la facultad de disponer sobre la residencia de los emigrados sin anuencia de la legación española, pues esa era la práctica establecida entre Madrid y Lisboa ${ }^{140}$. Istúriz lo aprobó e instó al representante español a que reclamara que los emigrados fuesen apartados de las fronteras.

Presente en Lisboa el ex-general Iriarte, al que Costa Cabral había mandado encarcelar en el castillo de Viana, González Bravo dirigió otra nota al conde de Lavradío para que precisase si el gobierno portugués iba a observar en esta cuestión la misma actitud que el anterior gabinete. Se sospechaba que las autoridades portuguesas pudieran consentir a los emigrados fijar libremente su residencia ${ }^{141}$.

La respuesta se retrasó un poco ya que existían desavenencias dentro del gabinete. El ministro plenipotenciario portugués en Madrid, barón de Renduffe, inducía a su gobierno a pensar que las reclamaciones de González Bravo eran fruto de su animadversión hacia la nueva situación política portuguesa, sin que existieran instrucciones del gabinete español. Llegó a informar a su gobierno que estaba resuelto retirarlo de la legación en Lisboa ${ }^{142}$.

Los emigrados conspiraban. La vigilancia sobre sus actividades se había relajado. Dispuesto a terminar con esa situación, González Bravo se entrevistó con el ministro de Negocios Extranjeros el 26 de junio. Procuró demostrarle que, si en algo no se ajustaba su actuación a las instrucciones recibidas, fue en haberlas suavizado. Y le enseñó varios documentos, uno de ellos del 31 de mayo, que contemplaba la posibilidad de traslimitación ${ }^{143}$. Ese acto equivaldría, según el conde de Lavradío, a una declaración de guerra.

El ministerio portugués, tras recibir la nota del 9 de junio, con las instrucciones enviadas a González Bravo el 31 de mayo pero sin citar la traslimitación, la trasladó al ministro británico en Lisboa "para que anunciase a su gobierno que podía llegar el Casus foederis». Declaró también que renovaría las órdenes

139426 González Bravo-Istúriz, 22 junio, AHN Estado 5412/1.

140 Nota González Bravo-conde de Lavradío, 17 de junio, ANTT MNE 452. Respondía a la enviada el día anterior por Lavradío, anexos 1 y 2 a R 422 González Bravo-Istúriz, 18 junio, AHN Estado 5412/1.

14i Nota R González Bravo-conde de Lavradío, 19 junio, ANTT MNE 432 y copia anexa a 424 González Bravo-Istúriz, 19 junio, AHN Estado 5412/1.

142 Los despachos del barón de Renduffe fueron el elemento que más peś en las deliberaciones del gabinece. "Así lo ha participado a la Reina Fma. el sr. Conde de Lavradío el día 23 del actual». $\mathbf{R}$ 428 González Bravo-Istúriz, 26 junio, AHN Estado 5412/1.

${ }^{143}$ Mostró además el despacho de 13 de junio en que se aprobaba la nota del 6 al conde de Lavradío, AHN Estado 5412/1. 
de internamiento y custodia de los emigrados. Bajo ningún pretexto se les permitiría acercarse a la frontera.

El ex-general Iriarte sería conducido a un depósito militar o recibiría pasaporte para una de las colonias portuguesas o para el extranjero. El mismo 26 de junio, el ministro del Reino llamó a Iriarte para comunicarle el ultimátum del gobierno portugués. Y se expidió las órdenes de internamiento ${ }^{144}$.

\section{La SUBLEVACión Miguelista}

Otro obstáculo que tenía que vencer el gabinete Palmela exa el levantamiento de varias partidas en favor del ex-infante don Miguel en las provincias del Minho y Tras-os-Montes ${ }^{145}$. Había llegado el momento de la «restauración nacional». Así lo proclamaba un manifiesto enviado desde Londres el 23 de junio, en nombre de Don Miguel y firmado por Antonio Ribeiro Saraiva y que iba a inspirar la sublevación miguelista.

Se atacaba a la Reina y a los liberales y sus aliados internacionales. Ante el desgobierno liberal, los portugueses reaccionarían en favor de la restauración, como lo hicieron en 1640. El pretendiente pedía al pueblo que prestase toda la ayuda al general inglés MacDonald, que tomaría el mando de sus fuerzas ${ }^{146}$.

Junto al manifiesto, una declaración firmada el día siguiente dando a conocer las intenciones de don Miguel, sus principios y las instituciones que implantaría. El punto central, el regreso al sistema absolutista. Se aboliría los parti$\operatorname{dos}^{147}$. La rebelión miguelista ponía en evidencia el fracaso de la coalición de los tres partidos, que lucharon unidos contra los Cabral ${ }^{148}$. Los septembristas habrían sido utilizados por los miguelistas ${ }^{149}$. La situación creada era muy deli-

144 Lavradio-González Bravo, 23 junio, ANTT MNE L ${ }^{\circ} 155$ y 430 González Bravo-Istúriz, 27 junio, AHN Estado 5412/1.

14427 González Bravo-Istúriz, 26 junio, AHN Estado 5412/1. Crónica Polltica. Noticias Extranjerar. Portugal: El Cacólico 2260 (I julio) 4-5.

146 Crónica Política. Noticias Extranjeras. Portugal: El Católico 2286 (28 julio) 214-215.

${ }^{14}$ La declatación, Crónica Política. Noticias Extranjeras. Portugal: El Católico 2283 (24 julio) 189-190, tornada de A Revoluçäo de Septembro.

tå «Ahi estāo já separados as tres fraç̧ōes -o partido miguelista busca desembaraçar-se da tutella dos seus collegas na ultima revolução, e já começa a operar por sua conta -o partido setembrista pede a grandes brados a demissão do ministerio actual, porque o não julga apta para dar o necessario desenvolvimento ás ideas revolucionarias; ... -a fraç̧ão cartista representado pelo gabinete, desamparada de todos, é instada para servir de degrao ao predominio exclusivo de um dos outros dois bandos".

IS2 «O partido miguelista vai lançando mao das armas, e já não pede, aspira sem ceremonia a chegar aos seus fins pela violencia ... Acceitou (o partido setembrista) os miguelistas, foi busca-los, por não se achar com forças para luctar só com o partido da ordem; e foi busca-los, sabendo, como hoje declara, que elles se ligavam ao partido do movimento na idéa de se aproveitarem das rendencias revolucionarias nimiamente exaggeradas para depois as dirigir ao destronamento da Rainha, ou 
cada. El ministerio se veía asaltado por los legitimistas y abandonado por los conservadores dinásticos ${ }^{150}$.

Las noticias que llegaban a la secretaría de Guerra no eran muy tranquilizadoras $^{151}$. El 1 de julio marchó a Oporto un regimiento. Como medida de precaución se formaría una división en el Minho ${ }^{152}$. Un decreto creó dos círculos administrativos: uno, integrado por los distritos de Oporto, Braga, Viana, Villa Real, Braganza y Aveiro; otro, por los de Vizeu, Coimbra y Guarda. En cada uno, una primera autoridad central con el título de jefe civil superior. Se daba mayor cohesión a la acción gubernativa «en aquellas partes del reino donde algunos movimientos sediciosos o el recelo de ellos así lo demandan»153.

Se nombró para los círculos administrativos del Duero y del Mondego al vizconde de Beire y a Fonseca Magalhaes. Las facultades extraordinarias que se les otorgó, duramente criticadas por juzgarlas innecesarias, enfrentaron al gobierno y a las autoridades de Coimbra ${ }^{154}$. La Junta de esta ciudad decidió disolverse, tenunciando a auxiliar al gobernador civil en la pacificación del distrito. Aunque, tras su llegada a la ciudad el 6 de julio, Fonseca Magalhaes quiso conciliar los ánimos, tuvo que escapar precipitadamente hacia Lisboa. El pueblo se alzó en armas y se negó a acatar las órdenes de la administración central. La Junta volvió a tomar el poder, rehusando obedecer al gobierno. La prensa local «lo acus(ó) de exagerar los mismos abusos que sirvieron de pretexto para derribar a su predecesor". Todos estos acontecimientos revelaban la debilidad del ministerio ${ }^{155}$.

pelo menos dar ensejo para esta obra». Texto fechado el 1 de julio y publicado en el periódico conservador lisboeta $O$ Telegrapho el día siguiente, anexo a 434 González Bravo-Istúriz, 2 julio, AHN Estado 5412/1.

150432 González Bravo-Istúriz, 27 junio, AHN Estado 5412/1.

151 Comunicaciones de los generales comandantes de los distritos de Beira Alta, Tras-osMontes, Oporto y Minho recibidas el 29 de junio, anexo a 434 González Bravo-Istúriz, 2 julio, AHN Estado 5412/1.

isz La prensa exaltada consideró la medida insuficiente y atacó al ministro de la Guerra, José Jorge Loureiro. Crónica Política. Noticias Extranjeras. Portugal. Lisboa, 1 julio: El Católico 2266 (7 julio) 52.

${ }^{133}$ Texto íntegro del decreto en Cnnica Politica. Noticias Extranjeras. Lisbaa, 6 julio: El Católico 2272 (13 julio) 101 .

194 «Este nombramiento era anómalo, excepcional, extemporáneo e impremeditado, por lo menos nosorros lo concebimos así. El gobierno, haciendo semejante nombramiento, que la ley no reconoce, en una época en que las agitaciones populares casi parecían extinguidas, y sin haber dado previamente el más remoto conocimiento a las auroridades de Coimbra echó por tierra todas las conveniencias que el buen sentido aconsejaba se le tuviese». Crónica Polltica. Noticias Extranjerar. Portugal. Coimbra 7 julio: El Católico 2276 (17 junio) 133.

15s "El gobierno carece de fuerza para reprimir el movimiento de Coimbra, y como es probable que éste oo tarde en ser imitado por el otro gran círculo administrativo, el gobierno tendrá que volverse a sepultar en esa nulidad absoluta, en esa acción mecánica y subalterna de que tan intempestivamente ha querido salirn. Crónica Politica. Noticias Extranjeras. Portugal: El Católico 2275 (16 julio) 125 .

Hispania, LX/3, núm. 206 (2000) 1001-1046 
Para aplastar el movimiento miguelista en Tras-os-Montes, se pidió ayuda a España. El 5 de julio, el barón de Renduffe, en una nota a Istúriz, solicitó la vigilancia en fronteras y puertos ${ }^{156}$. Se le contestó afirmativamente, pero recordando el incumplimiento de la promesa de Lavradío el 9 de junio acerca del internamiento de emigrados españoles 157 , reclamación que transmitió Renduffe al ministro de Negocios Extranjeros ${ }^{158}$. Hubo una respuesta inmediata a las notas de 17 de junio y 2 de julio, que denunciaban el permiso concedido a algunos emigrados para residir fuera de los depósitos, sin avisar previamente a González Bravo. Ese acto se distanciaba de los deseos de España, rompiendo con la práctica habitual del gobierno anterior ${ }^{159}$. Quiso justificarse Lavradío citando la nota que el 2 de mayo dirigió Istúriz al barón de Renduffe, explicando la licencia concedida a un sargento confinado en el depósito de Toledo para que residiese en Talavera de la Reina en contra de la voluntad del gobierno portugués de aquella época ${ }^{160}$.

Muchos emigrados vivían cerca de la frontera. Ni el ex-general Iriarte ni otros más estaban internados en los depósitos designados. Se les veía transitando por Lisboa ${ }^{161}$. Gozaba aquél de mucho prestigio entre los revolucionarios portugueses. Con otros expatriados, fue recibido por César de Vasconcellos,

\footnotetext{
156 *Estas providencias sắo:

$1^{\circ}$ Que ordens mui terminantes e positivas sejāo passadas ás authoridades das fronteiras, afin de que exerção a mais sevéra vigilancia na raia sêca contra a introducção de armas ou muniçoés de guerra, para dentro de Portugal, e do mesmo modo nos portos do sul proximos ao Algarve, e nos da Galliza proximos da provincia do Minho.

$2^{\circ}$ Que iguaes ordens sejāo enviadas ás authoridades de todos os portos maritimos deste reino, para impedirem a remessa ou carregamento de armas ou muniçōes de guerra para qualquer punto de territorio portuguez, ilhas adjacentes, e das possessōes ultramarinas de Sua Magestade Fidelisima.

$3^{\circ}$ Que se renovem ordens aos capitanes generaes da fronteira para que façāo desarmar e internar quesquer subditos portuguezes, suspeitos de perrenecer a facçāo do Usurpador, e que se nāo consinta que sob qualquer pretexro se demorem ali, ainda que chegen desarmados.

$4^{0}$ Que se expeção ordens ás authoridades das fronteiras de França, e que do mesmo modo se recommende ás de todos os portos de mar, e ainda com mais particularidad ás de Mediterraneo, para que vigien os subditos portuguezes que ali possāo entrar, sobre tudo vindos de Italia, fazendo prontamente sahir deste reino os que nao truxeran passaporte em regra, avisando o governo de Sua Magescade de qualquer outra circunstancia que chegar ao seu conhecimento, e que posse ter connexao con esta, ou outras tentativas revolucionatiasw, Renduffe-Istúriz, 5 julio, AHN Estado 5412/1.

157 Minuta nota Istúriz-Renduffe, 6 julio, AHN Estado 5412/1.

138 Renduffe-Istúriz, 8 julio, AHN Estado 5412/1.

139 Conde Lavtadio-González Bravo, 9 julio, ANTT MNE Lo 155, copia traducida en anexo 1 a 446 González Bravo-Istúriz, 10 julio, AHN Estado 5412/1.

${ }^{160}$ España desestimó esa alusión de Lavradío. No era comparable el peligro que suponía para Portugal el traslado de un emigrado a unas leguas del depósito, que la autorización para residir en cualquier punto de Portugal a un número indefinido de emigrados españoles.

${ }_{161}$ González Bravo-conde de Lavradío, 10 julio, ANTT MNE 452, copia como anexo 2 a 446 González Bravo-Istúriz, 10 julio, AHN Estado 5412/1.
} 
quien les prometió el auxilio de los progresistas. La revolución en España permitiría realizar la unión de ambos países con el título de «República Ibérica»162.

Vasconcellos tenía mucho peso en la política portuguesa. Había encabezado la comitiva de emigrados portugueses venidos de España. Junto a Jervis de Atouquia, Passos Manuel, José Estêvao y el vizconde de Andaluz formaron la comisión de los clubes revolucionarios que presentaron al duque de Palmela una exposición solicitando, entre otras medidas, cambios en el ministerio. Éstas eran las exigencias de la exposición: " $1^{\circ}$ Que se anulase el decreto de amnistía concedido a los revoltosos de Torres Novas en 1844, y que en su lugar se les declare beneméritos de la patria. $2^{\circ}$ Que se aprueben todas las gracias $\mathrm{y} \mathrm{em}$ pleos tanto civiles como militares, que fueron concedidos por los jefes de aquella insurrección. $3^{\circ}$ Que se reorganicen los regimientos número 12 de infantería y $1^{\circ}$ de cazadores que fueron disueltos por haberse reunido a los revoltosos de 1844. $4^{\circ}$ Que se destituyan a todos los comandantes y oficiales de los diferentes cuerpos del ejército que no merezcan la confianza del pueblo. $5^{\circ}$ Que sean destituidos los ministros de la Guerra y del Reino en el caso de que no sean inmediatamente cumplidas estas exigencias. $6^{\circ} \mathrm{y}$ último. Que el marqués de Saldanha sea igualmente destituido por no merecer la confianza del pueblo y que se complete el ministerio con personas de absoluta confianzan ${ }^{163}$.

Se intentó seducir algunos de los cuerpos del ejército español de observación. Esperaban los emigrados y sus amigos portugueses que González Bravo dejase la legación de Lisboa. Con estas expectativas continuaron llegando a Lisboa ${ }^{164}$.

\section{Giro PRogresista en Portugal y Reacción de ESPaÑa}

Al hostigamiento del liberalismo más radical, acentuado tras los sucesos de Coimbra, se sumaron las escaramuzas más o menos importantes del ejército con las guerrillas miguelistas en Ponte de Lima y Arcos ${ }^{165}$. Surgieron nuevos focos en Braga y Vizeu, donde se multiplicaban las partidas de adictos a don Miguel 166 .

Hubo que modificar el gabinete. María II exoneró de su cargo al ministro de la Guerra, marqués de Saldanha, y aceptó la dimisión de José Jorge Loureiro, ministro de Marina y Ultramar, y de Joaquim Filipe de Souré, ministro de Negocios Eclesiásticos y de Justicia. El duque de Palmela pasó del ministerio de Hacienda al de Negocios del Reino, y Mousinho de Albuquerque de este

\footnotetext{
162445 González Bravo-Istúriz, 9 julio, AHN Estado 5412/1.

163 Crónica Politica. Noticias Extranjeras. Portugal: El Católico 2280 (21 julio) 166.

164 Crónica Poltitica. Noticias Extranjeras. Portugal: El Católico 2280 (21 julio) 165-166.

16s Cnónica Polftica. Noticias Extranjeras. Portugal. Listora, 15 julio: El Católico 2281 (22 julio) 173.

166 Crónica Politica. Noticias Extranjertas. Portugal. Lisboa, 18 julio: El Católico 2285 (27 julio) 204.
} 
último al de Marina y Ultramar ${ }^{167}$. La presencia del vizconde de Sá da Bandeira y Joaquim Antonio de Aguiar acentuaba su color progresista ${ }^{168}$.

Preocupado por la influencia que los sucesos de Portugal pudieran tener en los emigrados españoles, el gobierno ordenó la aproximación de tropas a la frontera, convencido de la inutilidad de presentar más quejas y reclamaciones. Se rechazaría cualquier agresión ${ }^{169}$.

La aproximación de dos cuerpos de ejército a la frontera, uno reunido en Orense y otro en Huelva, bajo el mando directo de sus respectivos capitanes generales y la formación de otro que se reuniría en algún punto intermedio, tuvo eco en los ministros plenipotenciarios de Portugal y del Reino Unido en Madrid. El 23 de julio enviaron sus notas a Istúriz pidiendo explicaciones ${ }^{170}$.

El gobierno español no se consideraba obligado a comentar los movimientos de sus tropas dentro de su territorio pues era un acto de soberanía. Afirmado así su derecho, Istúriz recordó que la situación de los emigrados políticos españoles en Portugal era la causa principal. Los soldados no traspasarian el límite entre los dos países, si no eran atacados desde el otro lado. Volverían a sus acuartelamientos cuando el gobierno portugués confinara a los refugiados en depósitos alejados de la frontera ${ }^{171}$.

El tono se suavizaba en la respuesta a Bulwer. Se le entregó copia de la nota dirigida a Renduffe. La explicaciones mostraban «los lazos que unen a la Inglaterra con el Portugal» ${ }^{172}$. El problema con los emigrados era la base argumental para defender el expedición militar a la frontera. Solicitó Istúriz la

167 Suplemento al Diario do Governo 167 (19 julio 1846), anexo a 457 González Bravo-Istúriz, 20 julio, AHN Estado 5412/1. El decreto transfiriendo a Palmela del ministerio de Hacienda al de Reino, 19 julio, ANTT MNE 402 y ANTT MNE L 77.

«El ministerio ha quedado definitivamente constituido de la siguience manera: Presidente del Consejo y ministro de Negocios del Reino, duque de Palmela. Marina y Ulrramar, Luis da Silva Mousinho de Albuquerque. Guerra, vizconde Sá-da-Bandeira. Negocios Eclesiásticos y Justicia, Joaquín Antonio de Aguiar. Relaciones Exteriores, conde de Lavradío. Hacienda, Julio da Silva Sánchez». Corsnica Politica. Noticias Extranjeras. Portugal. Lủboa, 18 julio: El Católico 22285 (27 julio) 204-205.

168457 González Bravo-Istúriz, 20 julio, AHN Estado 5412/1.

169 González Bravo-Lavradío, 16 de julio, ANTT MNE 452.

170 "The amicable relations which subsist between the rwo governements of Spain and Great Britain, and the engagements which bind Great Britain to Portugal, authorise me to request from your excellency some explanation as to this excraordinary occurrence, which I cannot disguise from you, wile produce a strong sensation in England as well as in the adjoining kingdom» BulwerIstúriz y Renduffe-Istúriz, 23 julio, AHN Estado 5412/1.

171 Istúriz-Renduffe, 24 julio, AHN Estado 5412/2.

${ }_{172}$ Estos eran seculares. Vid. Tractados de alliança entre Portugal e a Grā-Bretanha: Tractado assignado em Londres a I6 de junho de 1373; em Windsor a 9 de maio de 1386 , em Londres a 29 de janeiro de 1642; em Westminster a 20 de julho de 1654; en Whitehall em 28 de abril de 1660; a 23 de junho de 1661 (incluye un artículo secreto); em Lisboa aos 16 de maio de 1703; en Vienna em 22 de janeiro de 1815. Extractos en apéndice OLA 357-367. 
mediación británica sobre el gobierno portugués para despejar «todo motivo de recelo y de perturbación»" ${ }^{173}$.

Quiso también mantener informado al gobierno francés y entregó una nota a su embajador en Madrid. La actitud portuguesa hacia España varió a raíz del cambio político ocurrido en mayo. Entre las causas de tensión, los emigrados españoles. No se atendió la petición de que se les confinara en depósitos lejos de la frontera. Recibían grandes facilidades para atentar contra los intereses españoles, rompiendo los acuerdos establecidos entre los dos gobiernos en esta materia. Así las cosas, se interrumpió la comunicación entre González Bravo y el ministro de Asuntos Exteriores portugués hasta «suspender toda reclamación y declarar expresamente... que estaba firmemente resuelto a no permitir que se tratara de perturbar el sosiego público de España y tomaría todas sus medidas, sin excluir la traslimitación para repeler con la fuerza de las armas toda tentativa armada que se preparase desde aquél con tal objeto" "174.

En Lisboa, la convocatoria de Cortes prevista para el 1 de septiembre fue aplazada hasta el 1 de diciembre mediante decreto de 27 de julio. En el mismo decreto se publicó la nueva ley electoral. Las elecciones generales serían directas. Se votaría a los diputados en los círculos electorales ${ }^{175}$.

En el terreno económico, la situación del Banco de Lisboa era cada día más crítica. Circularon sus billetes con un quebranto de casi un $10 \%$. Políticamente, el panorama era desalentador. La insurrección miguelista en el norte del país no estaba controlada. Los principales jefes cartistas intentaron una reacción militar. Sus promotores desistieron ante la falta de organización y la incertidumbre del resultado ${ }^{177}$. El partido progresista auxiliaba de forma abierta a sus correligionarios emigrados de España ${ }^{178}$.

Alarmado por la marcha de tropas españolas hacia la frontera, el barón de Renduffe ofreció garantías ${ }^{179}$. El capitán general de Galicia había ordenado

179 Istúriz-Bulwer, 26 julio, AHN Estado 5412/2.

174 Istúriz-Bresson, 27 julio, AHN Estado 5412/2.

175 «... cada um d'esses circulos deve dar um Deputado por cada 6.500 fogos. Portugal em si tem de ser dividido em vinte e cinco collegios eleitoraes; as illhas adjacentes em quatro; e as possessôes ultramarinas em sete». Howard de Walden-Palmerston, 29 julio, apéndice OLA 353-354.

176469 González Bravo-Istútiz, 31 julio, AMAE H 1687. Crónica Poltitica. Noticias Extranjerat. Portugal. Lisboa, 2 agosto: El Católico 2299 (10 agosto) 317.

177469 González Bravo-Istúriz, 31 julio, AMAE H 1687.

178 «Debe llamar también la atención la conducta que se observa con los 286 emigrados espanoles que están en Cascaes, pues aunque los soldados permanecen en este último punto, los oficiales se entretienen en conspirar en Lisboa para el santo fin de salvar a la patria, y asisten a todas las escenas de escándalo tales como la que dio el general Iriarte que en el teatro de doña María II respondiendo a los vivas que daba la patulea a los mismos emigrados dijo en alta voz de este modo: 'Vivan los que han librado a Portugal del yugo de un gobierno opresor, y que en breve han de concurrir para que la España quede libre de un gobierno semejante'». Crónica Política. Noticias Extranjeras. Portugal. Lisboa, 2 agosto: El Católico 2299 (10 agosto) 317.

179 Renduffe-Istúriz, 2 agosto, AHN Estado 5412/2. 
cortar las comunicaciones con Portugal a lo largo del río Miño ${ }^{180}$. Hubo una reclamación formal e inmediata del representante portugués. Siendo tan frágil en aquellas circunstancias el lazo que unía a los dos gobiernos, las medidas del capitán general de Galicia eran «de uma trascendente gravidade, e denuncião intençōes bern oppostas ás que V. Ex ${ }^{\mathrm{a}}$ tem procurado manifestar-me» ${ }^{181}$.

Enviada copia traducida al ministerio de Guerra el 7 de agosto, ese mismo día contestó a Istúriz que no existía ninguna comunicación que justificase la reclamación de Renduffe, salvo lo que indicaba el capitán general de Galicia en el artículo cuarto de las instrucciones dadas a los jefes de la línea de Portugal en 27 de julio ${ }^{182}$. A la vista de las disposiciones que empezaba a adoptar el gobierno de Lisboa para evitar que agentes de su país o expatriados españoles alterasen el orden en España, se aceptó la petición ${ }^{183}$.

El embajador portugués respondió el 6 de agosto a la nota del 24 de julio refutando los argumentos de Istúriz. Los datos eran einexactos", quizás por las «erróneas informaciones de sus agentes". España no tenía derecho a efectuar movimientos de tropas y concentrarlas junto a la frontera común, pues eso podría considerarse «como tendente a promover y proteger una revolución en Portugal». El gobierno portugués estaba dispuesto «a reclamar pronta y formalmente el cumplimiento de los tratados existentes entre S. M. F. y S. M. Bcan ${ }^{184}$.

Esos días se concentraban en Portugal emigrados políticos españoles procedentes de Inglaterra, Francia y Bélgica, que no tenían pasaporte. Se esperaba la llegada del general Juan Prim ${ }^{185}$. González Bravo se entrevistó el 7 de agosto con Lavradío. Los dos querían recuperar la confianza mutua. Por parte española, bastaba que el gobierno portugués vigilara a los exiliados y desbaratara su planes. Habían organizado batallones en los depósitos. Compraban caballos. Se gratificaba a los desertores de las tropas españolas. Cuando se acabara con esto, las tropas regtesarian de la frontera a sus acuartelamientos. No se pretendía amenazar a Portugal, sino preservar el orden dentro de sus fronteras.

180 Las autoridades españolas habian negado el pase al vicecónsul de Portugal en Tuy cuando el 31 de julio pretendía trasladarse a Valenza.

181 Se quejó de la falta de comunicaciones previas de gobierno a gobierno. Renduffe-Istútiz, 6 agosto, AHN Estado 5412/2.

${ }_{182}$ Oficio Guerra-Estado, 7 agosto, AHN Estado $5412 / 2$. Se copia el artículo $4^{\circ}$, que ordena a los jefes políticos de Pontevedra y Orense que sitúen destacamentos de cuatro o cinco hombres de Guardia Civil en determinados puntos para observar la frontera. Habrían de ponerse de acuerdo con las autoridades militares para adoptar otras medidas, tsiendo una de las principales el retirar todas las barcas del Miño a la derecha del mismo desde la Filgueira hasta la Guardia, tomando para ello todas las providencias que convengan y en las comprendidas desde Filgueira hasta Orense, encargando una extraordinaria vigilancia sobre toda clase de personas que transitan por ellas, deteniendo y arrestando a cuantas parezcan sospechosas, entregándolas a disposición de la autoridad militar más inmediata con los correspondientes cargos que resulten contra ellos».

${ }_{183}$ Istúriz-Renduffe, 8 agosto, AHN Estado 5412/2.

184 Renduffe-Istúriz, 6 agosto, AHN Estado 5412/2.

185474 González Bravo-Istúriz, 6 agosto, AHN Estado 5412/2. 
El ministro de Negocios Extranjeros le comunicó «... la alarma en que sin cesar tienen nuestros emigrados al gobierno portugués y su deseo de apartarlos de este reino". Se tomarían resoluciones enérgicas ${ }^{186}$.

El gobierno temía no sólo el contagio de la anarquía portuguesa a las provincias españolas limítrofes sino también la gran solidaridad entre el partido septembrista y los emigrados españoles, "che liberamente si preparano ad una invasione, o almeno fanno maneggi e attruppamenti in Elvas e altri luoghi presso il confine. Per le quali cose, il medesimo Ministero ha dichiarato che le truppe, le quali si adunnano al confine stesso, non solo sono per osservazione, ma anche per agire, secondo che richiederà la circonstanza, e la difesa dell'ordine pubblico nella propia nazione» ${ }^{187}$.

El 10 de agosto, una Real Orden del ministerio de la Guerra mandó a los capitanes generales de las provincias limítrofes de Portugal que retirasen las tropas concentradas en la frontera ${ }^{\text {l88. }}$.

En Londres, el duque de Sotomayor, embajador español, expuso a lord Palmerston las intenciones pacíficas y las razones de su gobierno ${ }^{189}$. Palmerston le informó de las medidas tomadas por el gobierno de Lisboa. Fijado el contencioso en la cuestión de «si el gobierno portugués en efecto había mandado internar a los emigrados políticos y si esta orden se había llevado a puntual y debido efecto", se convino que el español nombraría a dos oficiales de Estado Mayor para que, con otros dos portugueses, recorriesen la frontera para cerciorarse de que se había cumplido esa disposición. Si así era, se retirarían las tropas de la línea fronteriza ${ }^{190}$.

196 La conversación, amistosa, se cerró con el compromiso de no ahorrar esfuerzos para recuperar la cordialidad entre los dos gobiernos. 477 González Bravo-Istúriz, 10 agosto, AMAE H 1687.

197 1209 C. di Pietro-Secretario Estado, Lisboa 8 agosto 1846, ASV SS 250 (1846) 3 130-131.

198 Los puntos fijados para su estacionamiento eran:

"Provincia de Galicia. Las fuerzas que se hallaban en Puente Areas, Cañiza y Rivadavia, deben replegarse en dirección de Pontevedra y Carballino; y las de Orense en la de Monforte y Chantada.

Provincia de Castilla la Vieja. Las tropas debían situarse en Ciudad Rodrigo, Salamanca y Zamora.

Provincia de Extremadura. Las tropas debían rerroceder a Badajoz, teniendo en Olivenza y Alcántara las guarniciones ordinarias, y una pequeña partida móvil sobre la derecha del Tajo, en razón de hallarse inutilizado el puente de Alcáncara.

Provincia de Andalucía. Deben replegarse las tropas sobre la línea que marca el tío Tinto, sieuándose en su margen izquierdo en la dirección de los pueblos de Moguer, La Palma y Aracenaw. Real Orden ministerio Guerra-capitanes generales provincias limítrofes de Porrugal, Madrid I0 agosto. Enviada el día 12 a los pleniporenciarios de España en Lisboa, Londres y París. vid. minutas Istúriz-ministros plenipotenciarios en Lisboa, Londres y París, 12 agosto, AHN Estado 5412/2.

${ }^{189}$ Sobre Carlos Martínez de Irujo, duque de Sotomayor, que había tomado posesión como ministro plenipocenciario en Londres en enero de 1845 , puesto que desempeñatía hasta enero de 1847 , AMAE Personal $154 \mathrm{n}^{\circ} 8037$.

190477 duque de Sotomayor-Istútiz, Londtes 15 agosto. Sobre la misma conferencia, Palmerston-Bulwer, Londres 13 agosto, copia entregada por Bulwer el 5 de septiembre a Istúriz, AHN Estado 5412/2. Vid. también 1222 C. di Pietro-Santucci, Lisboa 14 agosto 1846 , ASV SS 250 (1846) 295 . 


\section{LA RECLAMACIÓN PORTUGUESA CONTRA LOS CABRAL}

Vino entonces a complicar la situación un dictamen del Consejo de Estado: los tratados hispano-portugueses no obligaban a la devolución de los soldados refugiados en Portugal tras amotinarse en el barco que los transportaba a $\mathrm{Cu}-$ ba. Con todo, el gobierno portugués ordenó que embarcaran en Oporto, a bordo del vapor de guerra "Mindelo", ochenta y dos oficiales, treinta y tres soldados y tres paisanos, todos ellos refugiados españoles ${ }^{191}$.

Los moderados españoles temían el iberismo de los progresistas. El proyecto podría llevarse a cabo con una monarquía de la dinastía de la casa de Braganza o bajo la forma republicana ${ }^{\mathrm{t} 92}$.

El gabinete portugués negaba que hubiera emigrados armados en la frontera. Difundian esa información los enemigos de la concordia entre los dos vecinos ${ }^{193}$. El ministerio inglés, que apoyaba totalmente al portugués, imputaba las tensiones existentes a González Bravo cuya parcialidad era el origen de la sospecha entre los dos gobiernos. Había además una causa política: el afán de restablecer en Portugal la situación anterior a la revolución del Minho. El trato que recibía a Costa Cabral en Madrid ${ }^{194}$ confirmaba la idea de que la alianza de sus enemigos, obligaba a las dos monarquías a homogeneizar sus instituciones ${ }^{195}$.

\footnotetext{
191 Además de los embarcados, «faltaron a la obediencia debida y dejaron de embarcar 32 de los pertenecientes a la clase de los primetos, 11 soldados y todos los demás civiles». Informe del cónsul español, Bernardo Roiz-González Bravo, Oporto 8 agosto, anexo a 477 González BravoIstúriz, 10 agosto, AMAE $\mathrm{H} 1687$.

${ }_{192}$ Sobre iberismo, J. Bta. VILAR, Las relaciones internacionales isabelinas: Precisiones conceptuales $y$ anotaciones bibliográficas (1833-1868): Las relaciones internacionales en la España Contemporánea, Murcia 1989, 37-77.

193 «Ma pare che non sia vero che i rifugiati siano in truppa verso la frontiera... Il Diario del Governo di qui, seggue ad affermare che il Governo di Spagna ha false notizie, e che tutti i Rifuggiati sono nell'interno".

«L'asserzione dell'esistenza degli emigrati armati nella frontiera è compiutamente priva di fundamento. Le Autorità Civili e Militari hanno ricevuco gli ordini più pressanti per mandare inmediatamen-nell'interno qualunque emigrato traspassi i confini del nostro Regno. Di più, il Governo diè la commisione ad alcuni ufficiali di Stato Maggiore di visitare le frontiere, e sorvegliare all'esecuzione degli ordini circa gli emigrati. Le Autorità Spagnuole non dovrebbero dar fede ad informazioni che non possono provenire se non degli inimici dei veri interessi d'ambe la Nazionin. 1210 y 1211 C. di Pietro-Santucci, Lisboa 9 agosto 1846, ASV SS 250 (1846), 3136 y 140.

194 «L'esule Capo del Governo già caduto, è a Madrid, e con molta distinzione; il Ministro di Spagna, che qui risiede, moscró assai malconcento della sua disgrazia, e tiene per cerco che due Sisterni di Governo non possono mantenersi a lungo nella Penisola; conviene, a suo parere, che presto o rardi l'uno si faccia omogeneo all'altro; perció debe bramarsi che i progressisti del Portogallo siano frenaci ed abbassati». 1210 C. di Pietro-Santucci, Lisboa 9 agosto, ib. 136.

199 *...la Spagna volontieri concorrerebbe a ristabilire il sistema Cartista, qual era prima della rivoluzione del Minho». 1209 C. di Pietro-Santucci, Lisboa 8 agosto 1846, ib. 130-131.
} 
Coincidiendo con los rumores de una posible conspiración cabralista abortada en la noche del 13 de agosto ${ }^{196}$ llegó a Lisboa la escuadra inglesa del almirante Parker ${ }^{197}$. Lo había pedido Howard de Walden ${ }^{198}$. Dejó Parker dos navíos en el puerto y salió el día 18 a vigilar las costas portuguesas. Se le unieron las fragatas "Raliegh", "Constance», «Eurydice» y "Sparta»"199.

Mientras, marchaban hacia Vigo la fragata de guerra española «Isabel II», la corbeta "Villa de Bilbao" y el vapor "Blasco de Garay». Iba a organizarse junto con otros navíos, una división naval en las costas de Galicia y Portugal. Estaría al mando el comandante Cruz, de la fragata "Isabel II». Cuando se efectuaba la retirada de las fuerzas españolas, se anunció la inmediata salida de González Bravo hacia Madrid, vía Cádiz ${ }^{200}$. Sería un triunfo de los revolucionarios $^{201}$. La protección evidente del gobierno británico al portugués había sido eficaz ${ }^{202}$.

François Guizot sugirió a Istúriz que fuera tolerante con el gobierno de Palmela y valorara las ventajas de una política que conciliara los derechos de su país y obtuviera garantías de cara a los emigrados ${ }^{203}$.

Istúriz afirmaba el 12 de agosto que, «en vista de las medidas que el gobierno de S. M. Fma. ha empezado a adoptar con los emigrados españoles en Portugal a consecuencia de las reclamaciones del de S. M. Católica, la Reina mi

196 En ella participaría ta Guardia Municipal, el regimiento 16 y el de lanceros. «Dícese que habían salido soldados expulsados de la Guardia Municipal para la casa de D. Carlos Mascarenhas, en Bemfice, y que desde allí lo debían acompañar para ponerse a la cabeza del movimiento. También se añadió que el proyecto consistía en proclamar la Carta pura, y en asesinar al duque de Palmela, al vizconde de Sá, Aguilar y otrosm. Se había descubierto «una conspiración cabralista, por lo que se hicieron ciento cincuenta prisiones» Crónica Politica. Noticias Extranjeras. Lisboa 14 agosto: $\mathrm{E} 1$ Católico, 2310 (22 agosto) 404-405.

${ }^{197}$ Su composición y artillado, Crónica Política. Noticias Extranjeras. Porzugal: El Católico, 2310 y 2313 (22 y 25 agosto) 405 y 429 .

198 Cónica Politica. Noticias Extranjeras. Portugal: El Católico, 2310 y 2320 (22 agosto y 1 de septiembre) $404-405$ y $486-487$.

199 Crónica Política. Noticias Extranjeras. Lisboa 24 agosto: El Católico 2320 (1 sepriembre) 486.

200 *Il Ministro di Spagna González Bravo partirá per Cadice il giorno due o tre del prossimo sectembre. Egli ha un congedo di sei mesi, ma non sembra che sia per ritornare, se non cangiano qui le cose». 1243 C. di Pietro-Santucci, Lisboa 29 agosto 1846, ASV SS 250 (1846) 3147.

201 «E la Spagna già cede in quanco al Portogallo, e si sa in modo quasi ufficiale che le sue truppe si ritirano dalle frontiere, e si dice che il Sigr. González Bravo, suo Ministro in Lisbona, avrà un congedo per ritornarsene a Madrid». 1226 C. di Pietro-Santucci, Lisboa 19 agosto, ib. 144-145.

202 «Los revolucionatios han celebrado por medio de convites patrióticos el triunfo que no sin razón creen haber conseguido con la salida del enviado español. Dicese que como muestra de gracitud van a ofrecer un rico presente a lord Howard, ministro inglés». Crbnica Politica. Noticias Extranjeras. Lisboa 23 agosto: El Católico 2320 (1 sepriembre) 486.

${ }^{203}$ El embajador francés informó de eun mouvement rétrograde» en las posiciones del ejército situado en la frontera. Conociendo las malas relaciones entre Istúriz y González Bravo, se abstuvo de citar las quejas de París contra él. 219 Bresson-Guizot, Madrid 23 agosto, AAE CP Espagne 828 7-10. 
Augusta Señora ha dado la orden para que las tropas reunidas sobre la frontera de ambos reinos se replieguen en mayor distancia de ella, dejando sólo los destacamentos de guardia civil necesarios para la observación de las órdenes sobre vigilancia y reconocimiento de documentos de los que transitan de un país a otrom 204. $^{2}$

El embajador portugués no estimaba correcta esta afirmación, pues las medidas con los emigrados se iniciaron en mayo, dos días después de la toma de posesión del conde de Lavradío como ministro de Asuntos Exteriores ${ }^{205}$.

El gobierno español, sin ánimo de avivar discusiones, expresó su voluntad de corresponder a las disposiciones amistosas del portugués. Jamás había pretendido intervenir en los asuntos internos de Portugal. Tampoco se creía obligado a justificar ante otra nación el movimiento de sus tropas. Las medidas de precaución adoptadas, en parte modificadas por el curso de los acontecimientos, cesarían ante «las pruebas de buena correspondencia que desde algún tiempo me complazco en reconocer en el (gobierno) de Lisboa" ${ }^{206}$. La conducta del gabinete portugués con los refugiados políticos era correcta ${ }^{207}$.

Explicó con detalle Renduffe los actos de su gobierno para impedir el desembarco en Portugal del infante don Enrique, Espartero y otros emigrados. Como pago, solicitó que se alejara a los hermanos Cabral de Cádiz y de Madrid para prevenir que promoviesen una reacción en Portugal ${ }^{208}$.

Istúriz, agradeciendo el control de Portugal sobre los revolucionarios para frustrar sus proyectos, no podía acceder a esta demanda. Los Cabral no eran emigrados políticos, hasta que no los considerara como tales el gobierno portugués ${ }^{209}$.

\section{UN BALANCE DEL MOVIMIENTO}

La insurrección miguelista estaba aún sin dominar. El conde das Antas se había desplazado a las provincias del norte para acabar con los últimos focos de resistencia. Fuentes oficiales afirmaban que lo había conseguido el 30 de agos-

204 Nota Istúriz-Renduffe, 12 agosto, copia a los representantes diplomáticos españoles en París y Londres con la misma fecha, AHN Estado 5412/2.

${ }^{205}$ Reclamó también Renduffe que las tropas españolas volviesen, según la nota de 24 de julio, «a las posiciones que anteriormente ocupaban». En la del 12 de agosto se decía «a la mayor distancia de la frontera". Renduffe-Istútiz, Madrid 28 de agosto, AHN Estado 5412/2.

${ }^{206}$ Respuesta a las notas de 6 y 28 de agosto, Istúriz-Renduffe, 31 agosto, AHN Estado $5412 / 2$.

${ }^{207}$ Eso pensaba el embajador francés en Lisboa. 123 y 124 Forth Rouen-Guizot, 5 y 9 septiembre. Sobre la comisión de oficiales ingleses enviada a la frontera entre los dos paises, 127 Forth Rouen-Guizor, 20 septiembre, AAE CP Portugal 176 10-13, 16-19 y 26-28. 2626.

208 Istúriz-Renduffe, 22 agosto, y nota confidencial Renduffe-Istúriz, 3 septiembre, AMAE H

${ }^{209}$ Nota confidencial Istúriz-Renduffe, 3 octubre, AMAE H 2626.

Hispania, LX/3, núm. 206 (2000) 1001-1046 
to. Era una buena noticia para España dada la conexión entre miguelistas y carlistas ${ }^{210}$.

Pero los medios no gubernamentales no compartían ese optimismo. El corresponsal del Comercio en Lisboa afirmaba que los movimientos miguelistas tenían mayor importancia que la que les daba el oficial Diario do Governo. Por esa razón reclamaban más tropas el conde das Antas para las provincias del norte y el marqués de Loulé para Coimbra. En las del Minho y Tras-os-Montes había una completa anarquía ${ }^{211}$. La prensa cabralista alarmaba a la población usando como argumento la insurrección miguelista, desmintiendo así las noticias dadas por el gobierno. La verdad era que los amagos rebeldes se extinguieron por sí solos ante la presencia de las tropas, a pesar de que los cabralistas agitaban a su favor. El gabinete estaba alertado y el conde das Antas había reunido bajo su mando varias divisiones militares en el norte del país ${ }^{212}$.

Con el partido cartista enfrentado al gobierno, temían en Lisboa una reacción desde que el marqués de Saldanha liegó a la ciudad el 23 de agosto, tras cinco años de ausencia. Los reyes de Portugal lo recibieron ese mismo día. Era un gesto político ${ }^{213}$.

Estando aún en el vapor «Pachá», se entrevistaron el 24 de agosto Saldahna y Lima, este último al frente de una diputación cartista. Le ofrecieron la dirección del partido ${ }^{216}$. Éste «só lhe pede, que, contando com o mais sincero apoio dos seus admiradores, e amigos políticos, aproveite a primeira opportunidade de salvar o Throno, a ordem, e as instituiçōes»215.

En Portugal, inquietaba a sus gobernantes la decisión que pudiera adoptar el marqués de Saldanha y los resultados de las inminentes elecciones. Inicialmente Saldanha no aceptó la oferta del partido cartista. Deseaba apartarse de la política interna. Pensaba renunciar al puesto de consejero de Estado, pues

210 Parte al ministro de Guerra, Diario do Governo 208 (Lisboa 4 septiembre) 929, anexo a 319 Cueto-Istúriz, 5 septiembre, AMAE H 1687.

${ }^{211}$ Crónica Politica. Noticias Extranjeras. Lisbaa 2 septiembre: El Católico 2329 (11 septiembre) 557.

212124 Forth Rouen-Guizot, Lisboa 9 septiembre, AAE CP Portugal 176 20-21.

${ }^{213}$ Dijeron a Saldahna «... que tinham querido ser as primeiras pessoas a falla-lhe; porque constando-lhes que muita genta se dispunha para o convidar a tomar a direcçāo de uma reaç̧āo contra o que se havia feito em Maio e Junho proximo passado queriam preveni-lo e declarar-le, que julgavam que hum tal acto augmentaria sem duvida as desgraças do Pais». Curtissima exposiçäo de alguns factos, Lisboa 10 agosto 1847, additamento OLA $1-3$.

214 «Em nome desse partido vimos nós tributar a V. Ex $x^{2}$ as suas homenagens, e rogar-le encarecidamente que unindo-se a homens dignos de V. Exa se empenhe em restituir a soberania ao Throno de nossos Reis, a authoridades á Carta de D. Pedro, e a independencia ao abatido Portugal». Lima-Saldanha, 24 agosto, additamento OLA 4-7.

215 Centro Cartista-Saldanha, 2 septiembre, additamento OLA 6-7 y AAE MD Portugal 17 $15-20$ y $23-26$. 
estaba persuadido de la imposibilidad de gobernar un país con unos partidos tan enfrentados. La Reina no aceptó su dimisión ${ }^{216}$.

Mirando a las elecciones, Sá da Bandeira dirigió una circular a los oficiales del ejército. En ella defendía los principios liberales. Los soldados votarían libremente. La presencia de la fuerza pública en los locales electorales debía ser escasa, sólo para preservar el orden y con requerimiento previo y por escrito de la autoridad civil ${ }^{217}$.

Los comicios se celebrarían en un clima de desafecto general hacia los Reyes. Se les reprochaba su indiferencia y su falta de valor. El pueblo odiaba a la camarilla palaciega, especialmente a Dietz, preceptor de los príncipes, y al padre Marcos, confesor de la Reina. AI primero se le acusaba de ser el causante de todos los males de Portugal. Se despreciaba a una clase política, considerada deshonesta. Parecía que nadie creía ya en el porvenir de su país.

El pueblo sacó sus conclusiones de la Revolución del Minho. Con su fuerza, incluso podrían enfrentarse al ejército. En adelante deberían contar con él. ¿Se había conseguido la integración de la población en la política?. En Portugal las revoluciones no fueron sangrientas.

Tenía Don Miguel instinto popular y lo apoyaba el clero. Las clases bajas estaban a su lado. Dentro del partido, los realistas, ligados a las clases altas, aceptaban los poderes constituidos. Muchos portugueses pensaban que la Reina protegía a los cabralistas, creyendo que estos le concedían ventajas en la lista civil del presupuesto.

Lisboa había cedido en beneficio de Oporto, Coimbra y Santarem. Su desprestigio era mayor en el norte. La destitución de los empleados de la antigua administración se consideró una represalia. Todos ellos formaban un núcleo de descontentos, prontos a servir a una intentona reaccionaria. La desconfianza de la población repercutió en la caída del crédito de los valores del Estado, de las sociedades autorizadas y de los billetes del Banco de Lisboa ${ }^{218}$.

Los partidos se hallaban muy divididos. El cabralista tenía una fracción de defensores de la Carta de 1826. En el bloque constitucional también se hallaban los cartistas ralliés, que regresarían inmediatamente a su primer partido, y los septembristas, moderados y exaltados, estos últimos contaban con una abrumadora mayoría. Los absolutistas estaban escindidos en miguelistas puros y realistas. Los últimos se adhirieron a doña María.

\footnotetext{
216 "Representação do marqués de Saldanha a María II", Lisboa 13 septiembre, AAE MD Portugal 17 14-15 y CP Portugal 176, 22-23 y additamento OLA 3-4.

${ }^{217}$ Un lenguaje nuevo. Hasta entonces las elecciones se hacian a la bayoneta. 129 Forth RouenGuizot, 23 septiembre, AAE CP Portugal 176 38-39.

218 Memoria del barón A. Le Mercier-Forth Rouen, Lisboa 10 septiembre 1846, AAE MD Portugal $14-13$.
}

Hispania, LX/3, núm. 206 (2000) 1001-1046 
En las elecciones, los cartistas propiciaban la abstención. Los septembristas se presentaban como los vencedores en la Revolución del Minho. El gobierno no deseaba intervenir ${ }^{219}$.

El 19 de septiembre se publicó el proyecto de programa con los puntos principales que los diputados del círculo electoral de Lisboa por el partido septembrista defenderían en las futuras Cortes. Con ese texto, la matizaciones redactadas el día 16 por J. B. d'Almeida Garret a cada uno de sus 26 puntos ${ }^{220}$.

Palmela visitó el mismo 19 de septiembre la legación de España. Manifestó sus deseos de propiciar amistosas relaciones entre los dos gobiernos. Había expedido órdenes terminantes para estrechar la vigilancia de los cerca de mil emigrados españoles ${ }^{221}$. Temía un triunfo de los demócratas en las elecciones ${ }^{222}$. Estaba dispuesto a mantenerse en el poder pues juzgaba un gran mal para su patria que cayese en manos de aquellos. Por ese motivo se puso al frente del país en circunstancias de gran tensión ${ }^{223}$. Las relaciones entre la legación de España y el gobierno portugués habían mejorado. Cada parte aportó moderación y no regateó su confianza a la otra ${ }^{224}$.

Escribió el 19 de septiembre Palmela una circular a los gobernadores civiles con el programa electoral del ministerio. Su meta, consolidar los logros del Movimiento Nacional de $1846^{225}$.

\footnotetext{
219 Acruaba con discreción. I29 Forth Rouen-Guizor, 23 septiembre, AAE CP Portugal 176 39-43.

${ }_{220}$ La carta explicando las opiniones de Almeida Garret sobre el programa estaba fechada en Oeiras el 18 del mismo mes. A Revolução de Septembro, 1603 (Lisboa 19 septiembre 1846), anexo 1 a R 334 Cueto-Istúriz, 21 septiembre, AHN Estado 5412/2.

221333 Cueto-lstúriz, 21 septiembre. Las órdenes no eran estrictamente cumplidas, como lo demuestra que Cueto tuviese que enviar una nota al conde de Lavradío el 1 de octubre para solicitar mayor eficacia, sobre todo en Viana y Oporto. El conde de Lavradío reconocía que, en esta última ciudad, el conde das Antas, comandante general de la División militar, era muy condescendiente con los españoles. Cueto envió esta nota sospechando que se promoviera «en España cualquier trastorno que impidiese la realización del enlace de la Srma. Sra. Infanta Doña María Luisa Fernanda con S. A. R. el Duque de Montpensiers. R 342 Cueto-Istúriz, 1 octubre, AHN Estado 5412/2.

222 Los exaltados estaban imponiéndose a Palmela, mientras los cartistas buscaban desligar el partido de los intereses de los hermanos Cabral. Estos eran favorecidos en España por El Heraldo. 130 Forth Rouren-Guizot, 24 septiembre, AAE CP Portugal 176 44-45.

${ }^{223}$ R 334 Cueto-Istúriz, 21 septiembre, AHN Estado 5412/2.

224132 Forch Rouen-Guizot, 2 octubre, AAE CP Portugal 17656.

225 «Rever a Carta de modo que os seus preceitos fiquem mais evidentes, e salvos de falsa e busiva interpretaçāo, será un novo culto á memoria saudosa do seu Augusco Auctor, e o cumprimento de uma vontade e desejo seu tantas veces manifescado. Reformar as leis criburarias de modo que os contribuientes pagem com a maior igualdade, e com o menor sacrificio possivel. Fazer una rigurosa revisāo dos quadros de todos os estabelecimentos; fixa-los inalreravelmente garantindo assim um progressivo e seguto augmento de economía. Fundar o credito nacional sobre estas bases, e prescrever o systerna de creditos phantasticos, ruina da fortuna pública e dos particulares. Dar real protecção ao commercio e á agricultura pela construcçāo de estradas e vias de communicaçāo. Diffundir a instrucção por todas as classes, fazendo com que a sciencia se derrame nas suas applicaçōes práticas
} 
El partido cartista, alarmado por la situación del país y el programa septembrista, volvió a requerir al marqués de Saldanha. Pretendía que accediese a la formación de un ministerio, si la Reina se lo solicitaba ${ }^{226}$. Saldanha expuso sus criterios sobre la formación de una nueva administración. De constituirse en ese momento, serían irrealizables la elección de diputados y la convocatoria de las Cámaras el día 2 de enero de 1847. Si ésta se verificase, a la vista del enfrentamiento entre los partidos, se bloquearía «a reorganisaçāo da sociedade que está quasi dissolvida». Era imprescindible aplazar un año la reunión de diputados y pares. Habría que dejarla para enero de $1848^{227}$.

El día 5 de octubre se publicó el programa definitivo de los septembris$\operatorname{tas}^{228}$. Los acontecimientos se precipitaron. María II tenía que optar entre el respeto al resultado de la libre expresión de la voluntad de los ciudadanos o aceptar una contra-revolución e incluso promoverla ${ }^{229}$. Ésta fue su decisión la noche del 6 de octubre. Se abría de este modo una etapa que llevaría a la guerra civil y a la intervención extranjera.

Desde el punto de vista de «la solidaridad occidental», formalizada en la Cuádruple Alianza, la cuestión de los «matrimonios españoles» mostró el intetés de la reina Victoria por el mantenimiento de la entente cordial con Francia. El enlace de Isabel II con el príncipe Leopoldo de Sajonia-Coburgo, primo del príncipe Alberto, marido de la reina Victoria, pareció la mejor solución. Los movimientos en torno a este asunto no eran ajenos a las perturbaciones que sufría Portugal ${ }^{230}$.

ás artes. Tractar sobretudo da educação moral do povo, provendo para o mesmo fim aos medios de educação e instrucção do clero. Organisar a força pública, e simplificar o systema administrativo e fiscal. Regutar as habilitações para a admissão aos empregos publicos. Finalmence fazer effectiva a responsabilidade de codos». Diario do Governo 222 (Lisboa 21 septiembre), 993, anexo 2 a R 334 Cueto-Istúriz, 21 septiembre, AHN Estado 5412/2.

226 Cencro Cartista-Saldanha, 23 sepriembre, additamento OLA 4-5.

227 Saldanha-Centro Cartista, 24 septiembre, additamento OLA 5-6.

228 Programma dos principios que a Associaçāo eleitoral setembrista deve manter nas côttes futuras, doc. III anexo a Howard de Walden-Palmerston, Lisboa 8 octubre, OLA 6-7.

229 «... parece que o resultado das eleiçōes setia tam duvidoso, que se julgou, depois da publicaçāo do programma Setembrista, que a corôa estava em tal perigo que menos risco corría expondose a uma contra-revoluçāo do que permittindo que as eleiçōes se fizeesem livremente como tinha sido proposto pelo Governo passadon. Howard de Walden-Palmerston, 8 octubre, OLA 3-4.

230 «... la revolución que está minando a este pobre país procede también del empeño que había en que se verificase el casamiento de la reina de España con el príncipe Leopoldo. Dícese que el ministro inglés hizo significar a SS. MM. que el único medio de lograr semejante enlace era fomentar y conseguir en España una revolución igual a la de Portugal, porque solamente de un ministerio progresista se podía obtener tal resultado. Hoy mismo ha llegado la noticia de la resolución del matrimonio con el infante don Francisco, y es por consiguiente natural que, perdida la esperanza del matrimonio Coburgo, varíe un poco la política en este país». Crónica Politica. Noticias Extranjeras. Lisboa 2 septiembre: El Católico 2329 (11 septiembre) 557. Sobre esta cuestión, TERESA PUGA, M: El matrimonio ..., o. c. J. Bta. VILAR, Las relaciones internacionales isabelinas: precisiones conceptuales $y$ anotaciones bibliográficas (1833-1868), (J. Bta. VILAR ed.), en Las relaciones internacionales en la 
Por eso el anuncio del doble matrimonio Francisco-Isabel y MontpensierLuisa Fernanda «... ne pouvait nous causer que de la surprise et un bien vif regret»231. Palmerston se opuso porque fortalecía la política internacional de Francia $^{232}$.

España Contermporánea. Murcia 1989, 37-77 y Las nelaciones internacionales de España (1834-1874), en Javier Paredes (coord.), Historia Contemporánea de España (1808-1939). Barcelona 1996, 307-338.

231 Así lo expresaba la Reina Victoria a la Reina de Francia el 10 septiembre, AAE CP Anglererre 66745 .

*Toutes les depêches et toutes les lettres confidentielles relatives à ces mariages (espagnols) avaient été gardées par Mr. Guizot et en f́́vriet 1848 il les a emportées chez lui avec plusieurs volumes des depêches qu'il avait fait copier dans les correspondances de nos embassadeurs et ministres à l'étranger. A sa mort le Ministère sera en droit de faire retirer tous ces papiers de sa sucession». AAE CP Angleterre 667, 68. Se hallan recogidos en AANN 42 Archivés Privés (AP) Papiers Guizot, 1-20 Correspondencia de su período como ministro de Asuntos Exteriores y especialmente 2, 1836-1847; 53 Bodas y 65 Correspondencia Bresson. Sobre matrimonios reales, Documents communiqués aux Chambres dans la session de 1846-1847, par le Ministre de Affaires Etrangères, Paris, janvier 1847, 83 pp. Documents communiqués aux Chambres dans la session de 1846-1847 par le Ministre de Affaires Etrangères, 2e. et 3e. communications, s. d. 43 pp. con anexos de documentos anteriores.

232 «La maniera onde è aggiustato questo progettato matrimonio; le mire politiche ch'esso manifesta in rapporto al futuro; le conseguenze possibili che arrecherebbe non pure alle amichevoli relazioni della Gran Bretagna con la Francia, ma anche alla pace di Europa in molti altri casi supponibili, inducono fortesemente il Governo Britannico a far delle rimostranze contro di esso, e ad esprimere le premurose sue speranze che questo matrimonio non conchiuda". 14 PalmerstonNormanby, Londres 22 septiembre, traducción italiana enviada por el nuncio en Lisboa, ASV SS 250 (1846), 2243.255 